\title{
SCHOOLING AND LABOR MARKET CONSEQUENCES OF THE 1970 \\ STATE ABORTION REFORMS
}

Joshua D. Angrist

William N. Evans

Working Paper 5406

\author{
NATIONAL BUREAU OF ECONOMIC RESEARCH \\ 1050 Massachusetts Avenue \\ Cambridge, MA 02138 \\ January 1996
}

We are grateful to Rich Robinson at CIESIN for providing Census extracts from the 1980 PUMS. Thanks also go to Phil Ellis for expert research assistance, and to Jon Gruber, Doug Staiger, and seminar participants at Hebrew University and the NBER Welfare of Children Workshop in May 1995 for helpful comments. Angrist's work on this project was funded by the NBER. Evans' work was funded by the National Science Foundation through grant SBR-9409499. The authors bear sole responsibility for the contents of the paper. This paper is part of NBER's research program in Labor Studies. Any opinions expressed are those of the authors and not those of the National Bureau of Economic Research.

(C) 1996 by Joshua D. Angrist and William N. Evans. All rights reserved. Short sections of text, not to exceed two paragraphs, may be quoted without explicit permission provided that full credit, including () notice, is given to the source. 


\title{
SCHOOLING AND LABOR MARKET \\ CONSEQUENCES OF THE 1970 \\ STATE ABORTION REFORMS
}

\begin{abstract}
This study uses the 1970 state abortion reforms to estimate the effect of teen and out-ofwedlock childbearing on the schooling and labor market outcomes of mothers observed in 1980 and 1990 Census microdata. Reduced-form estimates suggest that state abortion reforms had a negative impact on teen marriage, teen fertility, and teen out-of-wedlock childbearing. The teen marriage effects are largest and most precisely estimated for white women while the teen fertility and out-of-wedlock childbearing effects are largest and most precisely estimated for black women. The relatively modest fertility and marriage consequences of abortion reform for white women do not appear to have changed schooling or labor market outcomes. In contrast, black women who were exposed to abortion reforms experienced large reductions in teen fertility and teen out-of-wedlock fertility that appear to have led to increased schooling and employment rates. Instrumental variables estimates of the effects of teen and out-of-wedlock childbearing on the schooling and employment status of black women, using measures of exposure to abortion reform as instruments, are marginally significant and larger than the corresponding OLS estimates.
\end{abstract}

Joshua D. Angrist

Department of Economics

Hebrew University

Mt. Scopus

Jerusalem 91905

ISRAEL and NBER
William N. Evans

Department of Economics

University of Maryland

College Park, MD 20742

and NBER 
Teen mothers and especially unwed teen mothers have lower levels of educational attainment and are more likely to live in poverty than other young women (see, e.g., Furstenberg, 1976; Trussell, 1976; Card and Wise, 1978; Hofferth and Moore, 1979; Mott and William, 1985; Garfinkle and McLanahan, 1986; Hofferth, 1987). These well-documented differences do not prove that teen and out-of-wedlock childbearing has negative consequences, however. As many social scientists have noted, teen mothers might have been worse off than other women even if they had not had children at a young age ( see, e.g., Geronimus and Korenman, 1993). The best way to solve this omitted variables problem would be to conduct some sort of randomized trial that generates exogenous variation in teen fertility. In the absence of evidence from such an experiment, researchers must rely on exogenous natural variation combined with statistical modeling strategies to estimate the causal effects of teen and out-of-wedlock childbearing.

One strategy for identifying the causal link between teen childbearing and economic outcomes is to use instrumental variables (IV) that have generated exogenous fertility variation. A source of potentially exogenous variation is legislative changes. For example, several researchers have shown that changes in state and federal abortion legislation in the late 1960 s and early 1970 s had a substantial impact on fertility (e.g., Bauman, Anderson, Freeman, and Koch, 1977). The impact of abortion reform appears to have been especially large for teen and out-of-wedlock childbearing (e.g., Sklar and Berkov, 1974 and Levine, Kane, Staiger, and Zimmerman, 1995.) These findings suggest that abortion reform can be used to identify some of the effects of teen or out-of-wedlock childbearing on mothers.

In this study, we use abortion laws in women's state of birth to construct instrumental variables estimates of the effect of teen or out-of-wedlock childbearing on the schooling and labor market outcomes of teen mothers. In practice, the instruments are interaction terms between indicator 
variables for state of birth and year of birth. ${ }^{2}$ Using data from the 1980 Census, we are able to link conditions in a woman's state of birth to her fertility and the age distribution of her children. This information is then combined with data on schooling and labor market variables drawn from the 1980 and 1990 Census to assess the impact of teen and out-of-wedlock childbearing on these variables.

The paper is organized as follows. Following a brief overview of previous research on the economic consequences of teen and out-of-wedlock childbearing, the next section discusses state abortion reforms between 1967 and 1973 . We consider how these reforms are likely to have affected women who were teenagers at that time. Section II describes our statistical framework, along with some of the identification problems arising in that framework. Section III describes the Census samples and discusses the use of Census data to impute fertility histories.

The main body of evidence on the effects of abortion reform is collected in Section IV, where we present reduced-form estimates of the impact of abortion reform on fertility, schooling, and labor market outcomes. These estimates show a statistically significant association between teen fertility and abortion reform for both whites and blacks. The fertility consequences for whites are not very strong and there is little evidence of an impact of abortion reform on second-stage outcomes like schooling or employment status. In contrast, we find large fertility effects for black women. Moreover, the reduced-form estimates for blacks show a consistent pattern of fertility, schooling and employment effects. Section V presents two-stage least squares (TSLS) estimates of the effects of teen fertility for black women only. Section VI summarizes the findings and suggests some directions for further work.

${ }^{2}$ Card and Krueger (1992) used a similar strategy to estimate the effect of school quality in children's state of birth on the economic returns to schooling. Angrist and Krueger (1991) used stateof-birth and quarter-of-birth variation in the impact of compulsory attendance laws to identify the effect of schooling on wages. 


\section{BACKGROUND}

\section{A. Previous research}

At least two approaches have been proposed to overcome the problem of omitted variables bias in estimates of the effects of teen and unwed motherhood. The first compares siblings or cousins in the hope that omitted variables are shared by family members. Examples include Geronimus and Korenman $(1992,1993)$ who found mixed evidence for an adverse causal effect of teen fertility on teen mothers. One problem with this approach is that within-group comparisons are more likely to be biased by measurement error than conventional cross-sectional comparisons. A second problem is that within-family variation in fertility timing might actually be more strongly tied to unobserved individual characteristics than between-family variation. Finally, most within-family studies are based on small and possibly unrepresentative samples.

A second approach uses instrumental variables that generate exogenous variation in fertility. A study in this mold is Bronars and Grogger (1994), who compared outcomes for unwed mothers who had twins at first birth to the outcomes of unwed mothers who gave birth to singletons. Since twinning appears to be close to randomly assigned, this approach identifies the effect of having two children out-of-wedlock instead of one. Bronars and Grogger found that unwed mothers who gave birth to twins experience negative consequences relative to unwed mothers who gave birth to singletons. An obvious drawback of the twins approach is that the effect of having a second child is not necessarily the out-of-wedlock effect of primary interest.

Instrumental variables strategies that are based on individual or family background variables other than twinning can potentially identify the effect of having one child as a teenager. A recent example is Ribar (1994), who used age at menarche as an instrument to estimate the effect of teen childbearing on high school graduation in National Longitudinal Survey of Youth (NLSY) data. Simple comparisons of graduation rates and teen childbearing rates by age at menarche suggest that 
teen childbearing is negatively associated with high school completion. Another recent study is Hotz, McElroy and Sanders (1995), who used miscarriage as an instrument for having a baby in a sample of NLSY teenage girls who got pregnant at age 16. These authors found that a miscarriage of a teen pregnancy raises the schooling of would-be teen mothers but has little effect on their earnings.

\section{B. Changing abortion laws: 1967-73}

We use fertility variation associated with changing abortion laws in an attempt to identify the effects of teen and out-of-wedlock childbearing on mothers. This approach is implemented in samples of women who entered their teenage years in the late 1960s and early 1970 s.

A number of states (e.g., California) had partially liberalized their abortion laws by 1967 . By 1970, 15 states had adopted laws making abortion significantly easier to obtain (Sklar and Berkov, 1974). The 15 reform states (with the number of legal abortions per thousand women in 1971 reported in parentheses) are: New York (27.1), Hawaii (23.6), California (23.5), Washington (19.7), Alaska (17.4), Oregon (15.7), Colorado (9.1), New Mexico (7.1), Delaware (13.7), Maryland (11.4), Virginia (6.8), North Carolina (5.5), South Carolina (3.6), Arkansas (2.8), and Kansas (8.8). ${ }^{3}$ Four of these states (Alaska, Hawaii, New York, and Washington) adopted laws with virtually no restrictions on abortion in 1970 , while California adopted a regime of very liberal access to abortion. Researchers have linked the increased availability of abortion in this period to changes in the overall US birth rate, to a decline in teen births, and to a decline in out-of-wedlock births (see, e.g., Bauman, et al, 1977; Joyce and Mocan, 1990; Levine, Kane, Staiger, and Zimmerman, 1995; Sklar and Berkov, 1974).

Another source of variation in abortions potentially arises from more recent state laws

${ }^{3}$ The 15-state group discussed by Sklar and Berkov (1974) is listed in reports of the Centers for Disease Control (1974). Abortion rates in the text are from Sklar and Berkov (1974, Table 3). 
imposing restrictions on Medicaid funding of abortions or parental notice and consent. ${ }^{4}$ For the purposes of this study, however, we focus on women affected by the 1967-73 changes in abortion access because changes at that time were more dramatic than recent changes. Moreover, many of the women affected by the earlier changes have had time to complete their schooling and to enter the labor market by the time they are observed in the 1980 Census. We rely primarily on the Sklar and Berkov 15-state classification scheme to identify reform and non-reform states. Although other classification schemes might be equally plausible, the Sklar and Berkov classification is exogenous to our own exploratory empirical work. ${ }^{5}$

\section{The impact of the 1970 state reforms on teen exposure to legal abortion}

Our first goal is to link changes in legislation to teen and out-of-wedlock childbearing. Table 1 gives a stylized representation of the impact of abortion reform on women born in different years and in different states. The table presents a period-cohort diagram with years of birth on the vertical axis and calendar time on the horizontal axis for women born 1949-59. The entries in the left panel of the table show age in years.

Columns 1-2 in the right panel show the number of years of exposure to a liberalized abortion environment at ages 15-19, assuming that women born in reform states had access to abortion from

${ }^{4}$ Blank et al. (1994) found that restrictions on Medicaid funding of abortions resulted in lower abortions rates among state residents. Lundberg and Plotnick (1990) and Currie et al. (1993) found that NLSY women had a higher probability of bringing a pregnancy to term if they lived in a state that restricted Medicaid funding of abortions. In contrast, Levine, Trainor, and Zimmerman's (1995) findings suggest that Medicaid restrictions did not increase birth rates.

SIn their study of the effects of abortion reform on fertility, Levine, Kane, Staiger, and Zimmerman (1995) distinguish between New York, Washington, Alaska, Hawaii, and California, which they classify as "repeal states", and the 10 other states listed by Sklar and Berkov (plus Florida), which they classify as "reform states." Some of our TSLS estimation procedures also make use of this distinction. We note, however, that in 1971 substantial numbers of legal abortions were performed in reform states as well as repeal states (Sklar and Berkov, 1971, Table 3). 
1970 and women born in non-reform states had access to abortion from $1973 .{ }^{6}$ Columns $4-5$ show the number of years of exposure to a liberalized abortion environment at ages $15-19$, assuming that women living in reform states had access to abortion from 1971 and women living in non-reform states had access to abortion from 1974. For example, under this second coding scheme, a woman born in a reform state in 1954 spent three years between the ages of 15 and 19 in a liberalized abortion environment while a woman born in 1954 in a non-reform state spent no years between the ages of 15 and 19 in a liberalized environment. Columns 3 and 6 report the differences in years of exposure by year of birth and state-group. This difference ranges from 0 to 3 years. The last two columns report the age of first exposure as determined by the second exposure coding.

Years of exposure to a liberalized abortion environment is the key variable of interest in this study. We use the second exposure coding, based on 1971 and 1974 as reform years, because the resulting variable is slightly more strongly related to teen fertility than an exposure variable based on the first coding. One reason for this extra impact may be that abortion reform did not have an immediate effect on abortion access. Another reason is that exposure at ages 15-19 in 1971 and 1974 is the same as exposure at ages 14-18 in 1970 and 1973. Births at ages 15-19 are most affected by exposure one year earlier. It is important to note, however, that regardless of how exposure is coded, years of exposure in Table 1 is simply a compact parameterization of year-of-birth by state-of-birth interactions. We chose to focus on exposure instead of unrestricted year and state of birth effects because the exposure variable captures the impact of abortion liberalization on teen fertility in a convenient and parsimonious manner.

Our analysis of abortion reform involves two subsamples, corresponding to cohort-groups that we view as having been subjected to separate "experiments" in abortion reform. The first of these

6The vast majority of Americans spend their school-age years in the state where they are born (Card and Krueger, 1992). 
experiments is a consequence on the fact that women born after 1951 were more likely to have been exposed to a liberalized abortion environment as teenagers if they were born in a reform state than if they were born in a non-reform state. In contrast, there should be little difference in teen fertility patterns by state for cohorts born before 1952 because the 1970 reform period did not overlap with the teen years of these older cohorts. The first experiment ends with the 1954 cohort because younger cohorts were increasingly likely to have had teen exposure to national abortion liberalization in 1973 regardless of their state of residence.

The second experiment in abortion reform begins with women in the 1955 birth cohort. For the 1955 and younger cohorts, national abortion reform worked to close the gap in abortion legislation that was opened up by the 1970 state reforms. In particular, there was a 3 year gap in exposure by state group for women born in 1955 but there was no gap in exposure for women born in 1959.7 Our analysis of the second experiment ends with the 1959 cohort because younger cohorts have not completed their teen years by April 1980. Note, however, that while the two experiments are similar they are not necessarily symmetric. As we show below, it is easier to make the case for our identification strategy with the 1949-54 cohorts than with the younger 1955-59 cohorts.

Moreover, empirical results from the sample of women born 1955-59 show that, in practice, the national liberalization had little impact on the teen fertility of women born 1955-59. The 1973 national liberalization apparently did not constitute nearly as significant a change in abortion access as did the 1970 state reforms. ${ }^{8}$

'The 1954 cutoff for the first reform period is clearly somewhat arbitrary. The results change little, however, if we add the 1955 and 1956 cohorts to the first-experiment sample.

${ }^{8}$ Levine, Kane, Staiger, and Zimmerman (1995) conclude that state abortion reform in 1970 reduced birth rates 6-10 percent in reform states while national reform in 1973 reduced birth rates 3-4 percent in non-reform states. 


\section{IDENTIFICATION STRATEGY}

\section{A. Statistical framework}

The statistical framework captures both direct and indirect effects of exposure to abortion reform. Let $y_{i j}$ denote the $\mathrm{ith}$ observation on the $\mathrm{j}$ th outcome variable. The reduced-form relationship between exposure to a liberalized abortion environment and outcomes is estimated using the following equation:

$$
\mathrm{y}_{\mathrm{ij}}=\pi_{\mathrm{j}}+\sum_{\mathrm{c}} \mathrm{d}_{\mathrm{ic}} \delta_{\mathrm{cj}}+\sum_{\mathrm{s}} \mathrm{f}_{\mathrm{is}} \phi_{\mathrm{sj}}+\sum_{\mathrm{p}} \mathrm{e}_{\mathrm{ip}} \beta_{\mathrm{pj}}+\eta_{\mathrm{ij}}
$$

where $d_{i c}$ is a dummy indicating whether $i$ was born in year $c$ and $\delta_{c j}$ is a cohort-effect in equation $j$, $f_{i s}$ is a dummy indicating whether $i$ was born in state $s$ and $\phi_{s j}$ is a state effect in equation $j$. One state and cohort are omitted from the sets of state and cohort main effects; $\pi_{j}$ is a constant in equation $j$. The variable $e_{i p}$ is a dummy for $p$ years of exposure to a liberalized abortion environment between ages 15-19. $\beta_{\mathrm{pj}}$ is the corresponding exposure effect in the jth equation. In the empirical work, we measure exposure with 3 dummies for single-year groups, relative to the largest group, which is omitted. Therefore, for regressions in samples of women born 1949-54, women with 0 years of exposure make up the omitted group. For regressions in samples of women born 1955-59, women with 4 and 5 years of exposure are pooled in the omitted group. Years of exposure is determined by state of birth (reform/non-reform) and by year of birth using the second exposure coding in Table 1.

The years-of-exposure parameterization corresponds to a differences-in-differences or interaction-terms analysis of $y_{i j}$ for groups classified by state and year of birth. In the sample of women born 1949-54, for example, a dummy for one year of exposure is the interaction of indicators for being born in 1952 and for being born in a reform state. We prefer the years-of-exposure parameterization to less restricted alternative parameterizations because the former collapses some interaction terms into a single reference group (e.g., women with 0 years of exposure in the first experiment) and because it provides a convenient and compact labelling scheme. 
Estimates of equation (1) are of intrinsic interest because they provide a direct assessment of the impact of abortion reform. But estimates of equation (1) are also of interest because equation (1) provides the reduced form for a TSLS estimation strategy that identifies the effect of teen childbearing or other intervening variables on schooling and labor market outcomes. To see this, suppose the following equation is used to characterize the causal impact of an indicator of teen-childbearing $\left(\mathrm{y}_{\mathrm{ik}}\right)$ on the $\mathrm{jth}$ outcome $\left(\mathrm{y}_{\mathrm{ij}}\right)$ in a sample of adult women:

$$
\mathrm{y}_{\mathrm{ij}}=\alpha_{\mathrm{j}}+\sum_{\mathrm{c}} \mathrm{d}_{\mathrm{ic}} \Delta_{\mathrm{cj}}+\sum_{\mathrm{s}} \mathrm{f}_{\mathrm{is}} \Phi_{\mathrm{sj}}+\mathrm{y}_{\mathrm{ik}} \gamma_{\mathrm{jk}}+\epsilon_{\mathrm{ij}}
$$

The constant and the state and year of birth effects in (2) have been relabelled to distinguish them from the effects in equation (1). In this equation, the coefficient $\gamma_{\mathrm{jk}}$ captures what the outcome $\mathrm{y}_{\mathrm{ij}}$ would have been under alternative realizations of $y_{i k}$. The exposure dummies $\left\{e_{i p} ; p=1,2,3\right\}$ are available as instruments to identify these causal effects. We emphasize that the causal interpretation of TSLS estimates of equation (2) requires two things: first, the only reason for state and year of birth interaction terms in the reduced form equations for $y_{i j}$ and $y_{i k}$ should be exposure to abortion reforms; second, $y_{i k}$, should represent the only reason why the exposure dummies are related to the outcome, $y_{i j}$. Given these two assumptions, the TSLS estimates can be interpreted as producing an estimate of the average effect of $y_{i k}$ on $y_{i j}$ in the population of women whose value of $y_{i k}$ was affected by exposure to abortion reform (Angrist, Imbens, and Rubin, 1996).

\section{B. Identification problems in state-by-cohort analyses}

Equations (1) and (2) provide a framework that controls for additive state and cohort effects when analyzing state-of-birth by year-of-birth variation in abortion laws. A problem with this approach is that even if all the secular differences in completed fertility and schooling by state can be captured by additive effects, a sampling frame that interrupts schooling or fertility is likely to generate state-specific cohort trends. To illustrate this point in the case of schooling, suppose that everyone 
born in a reform state eventually graduates college at age 21 , while everyone born in a non-reform state stops attending school after graduating from high school at age 17. Although differences-indifferences contrasts for cohorts older than 21 will be zero, contrasts between cohorts aged 17-20 and older cohorts will show average schooling increasing with age (decreasing with cohort) in the reform states but not in the non-reform states.

For a more formal statement of this problem, suppose that there are actually no exposure effects in equation (1) for $y_{i}=$ years of schooling and suppose that all women born in cohort $c$ in state s ultimately complete $E_{s c}=\delta_{c}+\phi_{s}$ years of schooling. Suppose also that women are enrolled full time until they complete their schooling, so that schooling rises by one year for each year of age from the age they start school $\left(a_{0}\right)$. Let $c$ denote year of birth and let $t$ denote the Census year so that $(t-c)$ is age. As long as women are observed at a time where $(t-c)-a_{0}>E_{c s}$ then a simplified version of equation (1) holds:

$$
y_{i}=\sum_{c} \sum_{s} d_{i c} f_{i s} E_{s c}=\sum_{c} d_{i c} \delta_{c}+\sum_{s} f_{i s} \phi_{s} .
$$

Equation (3) has no interaction terms. But in general, one has

$$
\begin{array}{ll}
\mathrm{E}_{\mathrm{sc}}=\delta_{\mathrm{c}}+\phi_{\mathrm{s}} & \text { for }(\mathrm{t}-\mathrm{c})-\mathrm{a}_{0} \geq \delta_{\mathrm{c}}+\phi_{\mathrm{s}} \\
\mathrm{E}_{\mathrm{sc}}=(\mathrm{t}-\mathrm{c})-\mathrm{a}_{0} & \text { for }(\mathrm{t}-\mathrm{c})-\mathrm{a}_{0}<\delta_{\mathrm{c}}+\phi_{\mathrm{s}}
\end{array}
$$

This implies

$$
\mathrm{E}_{\mathrm{sc}}=\left[\delta_{\mathrm{c}}+\phi_{\mathrm{s}}\right]+\left\{\left[(\mathrm{t}-\mathrm{c})-\mathrm{a}_{0}-\left(\delta_{\mathrm{c}}+\phi_{\mathrm{s}}\right)\right] 1\left[(\mathrm{t}-\mathrm{c})-\mathrm{a}_{0}<\left(\delta_{\mathrm{c}}+\phi_{\mathrm{s}}\right)\right]\right\} .
$$

Equation (4) reflects the fact that when the sample includes cohorts that have not yet completed their schooling, there will be state-cohort interaction terms in average schooling even if there are no interaction terms in completed schooling.

The censoring problem that induces interaction terms in equation (4) can occur with any dependent variable that is an observation on an "interrupted spell." Examples include years of completed schooling and children ever born, and wages that increase with age. We therefore limit the 
analysis of 1980 Census data to variables that are least likely to have been interrupted. For example, measures of fertility such as teen-childbearing or the number of children born before age 20 are uncensored for women who are 21 or over. Similarly, the 1980 marital status data that is most useful for our purposes is an indicator of marriage by age 20 . Measures of early school progress like high school graduation status and college entrance are less likely to be censored than years of completed schooling. Censoring of schooling variables is also less likely to be a problem for the 1949-54 cohorts than for the $1955-59$ cohorts.

Finally, note that as a specification test we present estimates for men as well as for women. For example, we estimate equation (1) separately for the high school graduation status of men and women in the 1980 and 1990 Censuses. Because men are less likely to have been affected by abortion reform than women, the estimates for men provide a simple check on whether exposure effects are likely to be attributable to secular state-by-cohort interaction terms induced by censoring or other specification problems. ${ }^{9}$

\section{DATA AND DESCRIPTIVE STATISTICS}

The estimates were constructed using data from the 1980 and 1990 Census 5 percent Public Use Microdata Samples (PUMS; Bureau of the Census, 1983, 1993). Our 1980 Census samples consist of men and women born in the United States between 1949 and 1959 who identified themselves as black or white, discarding observations for which information on quarter of birth, age, or state of birth was allocated by the Census Bureau. The 1990 samples are similar to the 1980 samples, although the 1990 Census does not include information on quarter of birth. We therefore imputed a year of birth for the 1990 data based on age at last birthday and the fact that Census Day is

${ }^{9}$ Angrist and Krueger (1994) and Imbens and van der Klauww (1995) use similar cross-gender comparisons in instrumental variables analyses of the effects of compulsory military service on men. 
April 1. The 1980 Census extract includes observations on 420,920 white women born $1949-54$ and the 1990 Census extract includes observations on 445,402 white women born 1949-54. The 1980 Census extract includes observations on 61,778 black women born 1949-54 and the 1990 Census extract includes observations on 54,314 black women born 1949-54. Sample sizes for men and for women born 1955-59 are reported in the tables showing results for these groups.

\section{A. Fertility histories using 1980 Census data}

Our first empirical task was to construct measures of teen and out-of-wedlock childbearing from census data. Both census data sets record the number of children ever born (CEB). Other fertility information is derived exclusively from the 1980 Census because most of the children born to women in the 1949-59 cohorts will have left their mother's household by 1990 . To obtain detailed fertility information using the 1980 data, we used household identifiers to link children's records to mothers' records and then counted children in each mothers' household. Teen birth rates and cumulative teen fertility were determined by comparing the ages (in quarters) of mothers and children. Out-of-wedlock birth rates were estimated by comparing the oldest child's quarter of birth with the quarter of first marriage. Details are given in Appendix A.

We judged the success of the mother-child match by comparing our census-based fertility measures with vital statistics. Figure 1 plots the number of births per 1000 women as of December 31,1979 by year of birth for women born 1950-59. Two lines are drawn in the figure. The first shows fertility as reported in the 1980 census (i.e., self-reports of the number of children ever born). The second line shows the number of children ever born, as reported in National Center for Health Statistics (NCHS) vital statistics natality data derived from administrative birth records (NCHS, 
selected years [a]). ${ }^{10}$ The two lines are virtually parallel, although fewer births are reported in the census data than in vital statistics.

Two measures of cumulative teen fertility were computed from the census data. The first series (KB20_A) counts the number of children in the mother's household who are reported as having been born before the mother turned 20.11 The second series (KB20_B) subtracts the number of children in the mother's household who are reported as having been born since the mother turned 20 from the census CEB variable. The rationale for the second measure is that the self-reported CEB variable is probably more accurate than our count of children in the household. To see the relationship between $\mathrm{KB} 20 \_\mathrm{A}$ and $\mathrm{KB} 20 \_\mathrm{B}$, let KIDS be the number of children we count in the household. We can therefore write

$$
\mathrm{KB} 20 \_\mathrm{B}=\mathrm{CEB}-\left(\mathrm{KIDS}-\mathrm{KB} 20 \_\mathrm{A}\right)=\mathrm{KB} 20_{-} \mathrm{A}+(\mathrm{CEB}-\mathrm{KIDS}) \text {. }
$$

When this expression is negative we assigned zero to $\mathrm{KB} 20 \_\mathrm{B}$.

Figure 2 shows that KB20_A from the census data tracks the trend in the natality series well, but consistently misses $15-20$ percent of the births recorded in the natality data. KB20_B is closer to the natality series in absolute terms but appears to exaggerate the declining cohort trend in teen fertility. Figure 3 plots two corresponding census measures of the fraction of women who became teen mothers, along with a natality-based measure of teen fertility. The relationship between the census and natality series is similar in Figures 2 and 3.

${ }^{10}$ In these figures, year of birth refers to cohorts centered at January 1 for both census and vital statistics data. For example, the 1950 cohort includes women born in the second half of 1949 and the first half of 1950. See Appendix A for additional details on the comparison of Census and Vital Statistics data.

"We counted births up to and including the quarter the mother turned 20. Children's and mother's ages were computed using data on year of birth and quarter of birth. See Appendix A for details on how cumulative birth rates were derived from vital statistics. 


\section{B. Descriptive statistics and OLS estimates of teen-birth effects}

To motivate the subsequent analyses, Table 2 reports OLS estimates of the relationship between teen and out-of-wedlock childbearing, teen marriage, and selected outcomes for the 1980 Census sample, along with unweighted sample means. ${ }^{12}$ Results are shown separately for women born 1949-54 and 1955-59 and for blacks and whites. Fertility measures in the table were computed as discussed in the previous section. The indicator of teen out-of-wedlock births was coded as 1 if the mother's year and quarter of first marriage (both 1980 Census variables) preceded the date of birth of the oldest child in the household. The out-of-wedlock indicator used to construct the estimates reported in Table 2 counts only out-of-wedlock births to teenagers. The teen marriage indicator was coded using information on date of first marriage and the mothers' age.

The table shows that women from the younger birth cohort have schooling levels similar to those of the older cohort but are more likely to be in poverty in 1980 . Black women are much more likely than white women to have been teen mothers or to have had a child out-of-wedlock. For both white and black women, the rate of teen childbearing is somewhat lower for younger cohorts.

The OLS results are from models that include main effects for year of birth and state of birth plus the regressors of interest (entered one at a time). These results serve to document the fact that teen and out-of-wedlock childbearing are strongly associated with lower levels of schooling and higher poverty rates for young women. The negative association between teen or out-of-wedlock childbearing and outcomes is larger for younger cohorts than for older cohorts but this could indicate that older cohorts of teen mothers have had longer to catch up with other women. Another interesting relationship in the table is the finding that the negative association between teen marriage and outcomes is stronger for whites than for blacks.

${ }^{12}$ We do not compute OLS estimates using the 1990 census data because reliable fertility histories for women born 1949-59 cannot be computed from the 1990 data. 


\section{REDUCED-FORM RESULTS}

This section begins by establishing a link between exposure to abortion reform and teen and out-of-wedlock childbearing. We then explore the relationship between exposure to abortion reform and measures of schooling and labor market outcomes.

\section{A. Graphical analysis}

Some aspects of the relationship between exposure and other variables can be captured in plots by cohort and state of birth. Figures $4 \mathrm{a}$ and $4 \mathrm{~b}$ graph the number of children born before age 20 by cohort, by state of birth (reform/non-reform) and race for women born 1949-59 in the 1980 Census. The figures show declining trends in teen fertility for both racial groups in reform and nonreform states. The figures also show a somewhat steeper decline in teen fertility in reform states than in non-reform states for the 1951-54 cohorts. This steeper decline might be attributable to the effect of the 1970 liberalizations on teen childbearing. In contrast, the 1973 liberalization in non-reform states might be expected to have generated a reduction in the teen-fertility gap by state for cohorts born after 1956. There is no clear graphical evidence for such a pattern.

Teen marriage rates for women born 1949-54 are plotted in Figures 4c and 4d. The teen marriage rates exhibit similar cohort trends in each group of states, although for white women they appear to decline earlier and more quickly in reform states than in non-reform states. A possible explanation for this is that once abortion reforms took effect, women in reform states were less likely

to marry because of an unintended pregnancy than women in non-reform states. Figures $4 \mathrm{c}$ and $4 \mathrm{~d}$ also show a sharp overall decline in teen marriage rates by cohort in both sets of states. We have confirmed this decline in tabulations of data from the June Current Population Fertility Supplements and in US vital statistics data (NCHS, selected years [b]).

College entrance is one of the "second-stage outcomes" in our study, i.e., a variable that 
might have been affected by abortion reform because of the effect of abortion reform on teen and outof-wedlock childbearing.. The last pair of figures, $4 \mathrm{e}$ and $4 \mathrm{f}$, show college entrance rates by state and year of birth. Again, the cohort trends in reform and non-reform states are similar. The plot for black women also shows an increasing trend in college attendance in reform states relative to that in non-reform states, especially for women born before 1956.

\section{B. Exposure effects for women born 1949-54}

Table 3 reports estimates of $\beta_{\mathrm{pj}}$ in equation (1) for women and men born 1949-54 in the 1980 Census. Results are presented separately for blacks and whites. Each regression includes 3 exposure dummies, a constant, and a full set of main effects for year and state of birth. The omitted exposure group is 0 years. Means of all variables and sample sizes are also shown in the table. ${ }^{13}$ Standard errors for regression coefficients are given in parentheses.

\section{Fertility and marriage}

There is a modest but marginally significant association between abortion liberalization and reduced teen fertility for white women. For example, 3 years of exposure is associated with .012 (standard error $=.0036)$ lower teen birth rate and $.016(.006)$ fewer children (measured using KB20_B) than 0 years of exposure. These results imply that 3 years of exposure may have caused a roughly 5 percent reduction in the number of births to white teenagers. Overall, exposure to abortion reform is associated with no more than a 2.2 percent reduction in the number of teen births to white teenagers (this average is computed by dividing the average exposure effect for KB20_B by its mean).

${ }^{13}$ There are substantially fewer black men than black women in both the 1980 and 1990 Census extracts. This is largely attributable to the fact that information on key variables for black men is more likely to have been allocated by the Census Bureau, as well as to the historic undercount of black men in the Census (see, e.g., McCarthy, 1979). 
The fertility results for black women are much stronger than those for white women. Three years of exposure is associated with a $.045(.012)$ reduction in the probability of teen childbearing and $.068(.025)$ fewer children born by the age of 20 . The individual year-of-exposure effects for blacks are statistically significant for 1,2 , and 3 years of exposure in equations for all fertility outcomes in the table. The coefficients on 3 years of exposure amount to a nearly 10 percent decrease in the number of births to black teenagers. The results for black women also suggest that exposure had a strong impact on out-of-wedlock childbearing among teenage girls. For example, three years of exposure is associated with a $.045(.01)$ reduction in the probability of a teen out-of-wedlock birth. This is an 18 percent reduction in out-of-wedlock childbearing among black teenagers. In contrast, there is no evidence of an exposure effect on out-of-wedlock childbearing among white women. ${ }^{14}$

The differences in exposure effects by race reflected in Table 3 are consistent with Sklar and Berkov's (1974, Table 2) estimates of the change in teen out-of-wedlock birth rates between 1970 and 1971.15 Their estimates of out-of-wedlock childbearing rates among 15-19 year olds are repeated below:

\begin{tabular}{lccccccc} 
& \multicolumn{3}{c}{ White } & \multicolumn{3}{c}{ Nonwhite } \\
States & 1970 & 1971 & change & 1970 & 1971 & change \\
Reform & 1.37 & 1.18 & -.19 & 8.03 & 7.41 & -.62 \\
Nonreform & 1.08 & 1.02 & -.06 & 9.74 & 10.01 & .27 \\
Difference & & & -.13 & & & -.89
\end{tabular}

For whites, teen out-of-wedlock birth rates fell by only .13 percentage points more in reform states

${ }^{14} \mathrm{We}$ also estimated models where one dummy for any exposure was interacted with two dummies indicating the groups of 5 repeal states and 10 reform states classified by Levine, Kane, Staiger, and Zimmerman (1995). Results of this model for KB20_B show no significant exposure effects in either state group for white women. Results for black women are that any exposure is associated with a $-.077(.029)$ effect on KB20_B in repeal states and a $-.054(.020)$ effect in reform states.

${ }^{15}$ Sklar and Berkov derive their estimates of out-of-wedlock birth rates from state birth records. 
than nonreform states. For nonwhites, however, teen out-of-wedlock birth rates fell by .62 percentage points in reform states while rising .27 percentage points in nonreform states. This difference in changes is .89 , equal to about 11 percent of the average teen out-of-wedlock birth rate.

In contrast to the weak fertility effects for whites, Table 3 shows a precisely estimated negative effect of abortion liberalization on the probability a white woman got married by age 20 . For example, 3 years of exposure is associated with a $.029(.004)$ reduction in the probability of teen marriage, amounting to a 5.2 percent decrease in teen marriage rates. Estimates for white men born 1949-54 also show a much smaller and less precisely estimated association between exposure and teen marriage. The exposure effects on teen marriage for white men do not necessarily weigh against a causal interpretation of the effects for white women because reforms that affected marriage rates among women necessarily affected some men of roughly the same age from the same states. There is also a modest, close-to-significant, association between exposure and teen marriage for black women. But this relationship is much smaller and less precisely estimated than the teen fertility effects for black women.

\section{Other outcomes}

For reasons discussed in the previous section, analysis of the 1980 Census focuses on outcomes that are least likely to be censored for young women. Two schooling outcomes that unlikely to be censored are high school graduation status and college entrance rates. Results for poverty and employment status are also presented because these variables may be a better indicator of a young woman's ultimate labor market status than say, wages.

The F-tests in Table 3 provide no evidence of an association between exposure and any of the 
schooling or labor market outcome for white women in $1980 .{ }^{16}$ But we do find significant effects of increased exposure on the poverty status of white men. The effects for men could be due to the reduced teen marriage rate among men with more exposure if marriage raises wages or hours worked. However, because there are no corresponding poverty effects for white women, we believe the poverty effects for white men are spurious and reflect a state-specific cohort trend in this group.

Estimated exposure effects for black women show a statistically significant association between exposure to abortion reform and an increase in high school graduation rates, with one significant exposure effect in the same direction for college entrance rates (a single dummy for any exposure is also significant in this equation). Importantly, there is no evidence of corresponding effects for men. The table also shows statistically significant effects of exposure on employment status. In later analyses, we use TSLS to assess the impact of teen fertility on schooling and employment status implied by these reduced-form results.

\section{Results from the 1990 Census}

Table 4 reports results from the 1990 Census analogous to those in Table 3 for the 1980 Census. ${ }^{17}$ Note that data from the 1990 Census cannot be used to estimate the impact of exposure on detailed fertility outcomes because children are no longer observed in the mother's household in 1990. The only 1990 fertility outcome is CEB as reported by the mother. Similarly, there are no results for teen marriage because the 1990 PUMS does not include information on the date of first marriage.

${ }^{16}$ In view of the large sample sizes being analyzed here, it may seem inevitable that statistically significant results will always be obtained. The results for white women show that this intuition is incorrect. The coefficients of interest here are small interaction terms. To detect these small effects requires large samples. The samples used here are clearly not so large that the power function for a conventional t-test or F-test against a null hypothesis of no effect is close to one.

${ }_{17}$ The table reports weighted least squares estimates of equation (1) using 1990 data and the 1990 PUMS sampling weight. Unlike the 1980 PUMS, the 1990 PUMS is not self-weighting. 
Note also that there is no quarter of birth variable in the 1990 PUMS. Our imputation of year of birth and years of exposure to abortion reform is therefore less accurate with the 1990 data.

Outcome variables are less likely to be censored in 1990 than in 1980 . Table 4 therefore reports results for a wider range of outcomes than Table 3. The estimates in Table 4 for white women show no consistent evidence of a relationship between exposure and outcome variables of any kind, including CEB. The equation for poverty rates shows a marginally significant relationship but one of the significant single-year exposure effects is positive and the other is negative.

Results from the 1990 Census for black women show a marginally significant association between exposure and black college entrance. For example, black women with 3 years of exposure have a .03 (.013) higher probability of entering college. On the other hand, the strength of the evidence for a true schooling effect on women in 1990 data is diluted by the presence of a statistically significant effect for men at one year of exposure. Moreover, when the three exposure dummies are replaced by a single dummy for any exposure, the resulting college-entrance exposure effects are insignificant for both men and women.

There are at least two explanations for the lack of a clear pattern of statistically significant exposure effects in the 1990 data. First, women for whom teen fertility led to reduced schooling may have had time to partly catch up with other women by 1990 . Second, as noted above, the dating of a woman's teenage years is necessarily less accurate with the 1990 data. To investigate the possible impact of this measurement problem, we repeated the original analysis of 1980 data underlying Table 3 with the modification that data on quarter of birth are ignored when calculating year of birth. This experiment led to a substantial reduction in the precision of estimated exposure effects on the schooling of black women in the 1980 data. 
Pooled Estimates for 1980 and 1990

To sharpen the findings in Tables 3 and 4, Table 5 reports the results of estimating equation (1) using pooled 1980 and 1990 Census samples. The pooled regression models allow for separate year of birth and state of birth effects in each data set plus a dummy for 1990 data. The exposure effects were restricted to be the same in both the 1980 and 1990 data sets. ${ }^{18}$ The coefficient estimates in Table 5 are from models where the 3-dummy parameterization was collapsed into a single dummy for any exposure (i.e., an indicator for exposure $>0$ ). F-statistics are also reported for the joint significance of 3 exposure dummies as in Table 3.

Table 5 shows a pattern of statistically significant exposure effects on the schooling and employment status of black women, similar to the pattern found in 1980 but more precisely estimated. The causal interpretation of the results for black women in Table 5 is bolstered by the fact that there are no significant exposure effects on any outcomes for black men. There is also a consistent pattern of significant estimates for 3 different schooling outcomes. In contrast, there appear to be no effects of any kind for white women, other than a marginally significant negative estimate for high school graduation status. But 3 exposure dummies are not jointly significant in equations for the high school graduation status of white women (F-statistic p-value $=.13$ ), or any other outcome.

We also note that, as with results for 1980 , there is a statistically significant effect for white men in the stacked results, in this case for log annual earnings. But there is no corresponding earnings effect for white women. The only first-stage effect that could explain the earnings effect for white men is a slight reduction in teen marriage rates (the any-exposure effect on teen marriage for white men in 1980 is -.0075 with a standard error of .0029 . The implied IV estimate of the effect of teen marriage on log male earnings is $.0128 / .0075=1.7$, which is clearly too large to be plausible.

18The pooled estimation is complicated slightly by the fact that the 1980 data are self-weighting while the 1990 data are not. When constructing pooled estimates, we used a weight of 1 for each 1980 observation and normalized 1990 weights to sum to the sample size for each sex-race group. 
It therefore seems likely that the exposure effects on the annual earnings of white men, like the exposure effects on the poverty rates of white men, are spurious and attributable to a state-specific cohort trend for this group.

\section{Exposure effects for women born 1955-59}

This section reports results for the sample born 1955-59 using the 1980 Census data. As discussed in Section I, data for this group offer the opportunity to analyze the impact of national abortion liberalization. Applying the second exposure coding in Table 1 to cohorts in this sample, years of exposure varies from 1 to 5 years for women born 1955-59 in non-reform states and from 4 to 5 years for women born in reform states.

Table 6 reports the results of fitting equation (1) to selected first-stage outcomes in the 1955 59 sample. To facilitate comparisons with results for the older cohort, the 4 and 5 years-of-exposure groups were pooled so that, as before, there are 3 exposure dummies indicating effects of 1-3 years of exposure relative to a large reference group. In this case, however, the reference group consists of women with 4 or 5 years of exposure instead of 0 years of exposure because the former is the largest exposure group among the 1955-59 cohorts.

In contrast with the estimates for the older group, the estimates in Table 6 show no evidence of a statistically significant impact of national liberalization on any measure of teen fertility, out-ofwedlock childbearing, or teen marriage for either white or black women. For example, the Fstatistics for joint significance of the exposure dummies in the equations for teen childbearing by black women are virtually zero. Similarly, test results from the equation for white women's teen marriage rates have a marginal significance level of .11.

An alternate use of data for the 1955-59 cohorts is to combine it with data for the 1949-54 cohorts. We found that the estimated exposure effects for first and second-stage outcomes change 
little when the 1955 cohort is added to the older sample. The results are also similar, though somewhat less precise, when both the 1955 and 1956 cohorts are added to the older sample. But estimation pooling all of the cohorts born $1949-59$ generates statistically significant effects for the schooling of black men. There is no first-stage relationship in the pooled data (e.g., for teen marriage rates) to support a causal interpretation of these effects. We therefore focus on the cohorts born 1949-54 in the remaining empirical work.

\section{Additional reduced-form results using alternate state groupings}

Before turning to the IV and TSLS estimates, we briefly outline findings from two alternate approaches to reduced-form estimation using 1980 Census data on the 1949-54 cohorts. The purpose of these additional analyses, which are discussed in detail in Appendix B, is to further probe the main results. To make the presentation more concise, results in the appendix are based on models where, as in Table 5, the 3 exposure dummies have been replaced by a single dummy for any exposure. Note that the appendix table reports heteroscedasticity-consistent standard errors as well as conventional standard errors. Because the heteroscedasticity-consistent standard errors are virtually identical to the conventional standard errors, they are reported in the appendix table only.

The first set of alternative estimates repeats the original estimation in a sample that excludes non-reform states bordering on reform states. The excluded states are listed in the appendix. The rationale for this variation is a possible improvement in precision because residents of non-reform states bordering on reform states were partly affected by reforms. In practice, estimates without border states are remarkably similar to the main set of estimates, though somewhat less precise.

The second set of alternate estimates matches reform and non-reform states on the basis of average CEB and average years of schooling among women born 1949-50 in the 1980 Census. The rationale for this is an attempt to improve the control for state-specific cohort trends by ensuring that 
two key outcomes are similar across states for those cohorts affected least by abortion reform. Most of the estimates using the matched sample are relatively imprecise, but the exposure effects on black fertility are generally larger than the corresponding estimates using all states. In contrast with the estimates for teen marriage effects among white women, however, which remain statistically significant regardless of which states are compared, the teen marriage effects for black women are insignificant when estimated using matched samples or excluding border states.

\section{TSLS AND SSIV ESTIMATES FOR BLACK WOMEN}

The reduced-form results from 1980 and the pooled data paint a consistent picture of exposure effects on the fertility, schooling, and employment status of black women born 1949-54. This section uses TSLS estimation of equation (2) to tie some of these reduced-form results together. The results of TSLS estimation are reported in Table 7.

Exposure to abortion reform is related to a number of first-stage outcomes for black women, so that the choice of endogenous regressor for TSLS estimation is not automatic. For the purposes of Table 7, we chose to present results from models where KB20_B and a dummy for teen out-ofwedlock childbearing are the endogenous regressors. These choices are motivated by Table 3 , which shows that KB20_B is the first-stage variable for which exposure effects are the largest and teen outof-wedlock fertility is the first-stage variable for which exposure effects are most significant. Because these variables need not be the sole mechanism by which exposure to reform affected outcomes, the TSLS estimates should be viewed as providing one of a number of possible interpretations for the reduced form results.

Panel A of Table 7 reports TSLS estimates using 1980 data only. As in Table 3, the outcome variables in Table 7 are dummies indicating high school graduation, college entrance, poverty status, and employment status. The table reports IV estimates using a single dummy for exposure greater 
than zero as an instrument, TSLS estimates using 3 exposure dummies as instruments, and TSLS estimates using a single dummy for exposure greater than zero interacted with two dummies indicating repeal and reform states as classified by Levine, Kane, Staiger and Zimmerman (1995). As before, the first and second stage equations include a full set of state and year effects.

The estimates in Panel A show large, marginally significant effects of both first-stage variables on schooling outcomes and employment status. The estimates suggest that teen fertility caused a reduction in high school graduation and college entrance rates equal to 22-24 percentage points per child. The estimates are even larger when teen out-of wedlock births is taken to be the endogenous regressor because the corresponding first-stage effect is smaller. Note, however, that the chi-square statistics for over-identified models in column (b) favor the use of cumulative teen fertility as the endogenous regressor in models for high school graduation and employment status.

It is not possible to compute conventional IV or TSLS estimates using the 1990 data because there is no first-stage information in the 1990 data set. We therefore used the split-sample instrumental variables (SSIV) estimator introduced by Angrist and Krueger (1995) to combine the 1980 first-stage with 1990 data on outcomes. The SSIV procedure constructs cross-sample fitted values from the 1980 first-stage coefficients and the instruments in the 1990 data. The second stage estimates are then produced by regressing 1990 outcomes on the cross-sample fitted values. ${ }^{19}$ The SSIV estimates are reported in Panel B of Table 7. SSIV estimates of the impact of teen and out-ofwedlock fertility on college entrance using 3 exposure dummies are marginally significant. Other SSIV estimates, although not significant, have the same sign as the 1980 estimates.

${ }^{19}$ SSIV coefficient estimates are consistent under the same assumptions as conventional TSLS estimates, with the additional requirement that the reduced form relationships be the same in the two data sets. The SSIV standard errors reported in Table 7 were computed under the simplifying assumptions that the second-stage regression errors are homoscedastic and the coefficient of interest is zero. These assumptions imply that the conventional software-reported standard errors in the second stage of SSIV estimation are consistent (Angrist and Krueger, 1995). 
Note that all of the statistically significant IV and TSLS estimates in Panels A and B of Table 7 are actually larger than the OLS estimates. This suggests that the OLS estimates are probably not too big. On the other hand, the fact that the significant IV estimates are large is not surprising since, given the associated standard errors, any significant IV estimate must be large. ${ }^{20}$ In fact, based on the standard errors reported in the table, we could not have detected effects the size of the OLS effects in TSLS estimation with a single data set. It is therefore important to explore strategies for TSLS estimation that generate more precise estimates.

Panel C of Table 7 reports the results from a "stacked" TSLS estimation procedure that pools 1980 and 1990 data in a manner analogous to the models used to produce the pooled reduced-form estimates reported in Table 5. Stacked TSLS is a variation on SSIV that generates more precise estimates. The procedure works by computing conventional first-stage fitted values for 1980 data and cross-sample fitted values for 1990 data, as with SSIV. Denote these fitted values by $\hat{y}_{i k t}$ where subscript $t(t=80,90)$ denotes the two data sets. The second stage of stacked estimation fits

$$
\mathrm{y}_{\mathrm{ijt}}=\mathrm{X}_{\mathrm{i}} \alpha_{\mathrm{jt}}+\sum_{\mathrm{c}} \mathrm{d}_{\mathrm{ic}} \Delta_{\mathrm{cjt}}+\sum_{\mathrm{s}} \mathrm{f}_{\mathrm{is}} \Phi_{\mathrm{sjt}}+\hat{y}_{\mathrm{ik} \mathrm{k}} \gamma_{\mathrm{jk}}+\epsilon_{\mathrm{ijt}}
$$

in the pooled sample, where $\alpha_{\mathrm{jt}}, \Delta_{\mathrm{cjt}}$, and $\Phi_{\mathrm{sjt}}$ are separate effects for covariates, year of birth, and state of birth in each data set. The difference between the stacked procedure and SSIV is that the SSIV second stage excludes the 1980 data.

The stacked coefficient estimates, reported in Panel C of Table 7, lie between the 1980 estimates and the 1990 estimates. These estimates have standard errors that are smaller than the single-data-set standard errors. In some cases, the standard errors are small enough that the

${ }^{20}$ Another reason the IV estimates are larger than the OLS estimates is that even if the OLS estimates have a causal interpretation, IV and OLS estimators do not estimate the same parameter. In particular, if the response to treatment (in this case, teen fertility) is heterogeneous, then OLS captures a variance-weighted average response while IV captures the response for those whose treatment status was changed by the instrument (see Angrist, 1995 and Angrist, Imbens and Rubin, 1996). 
corresponding OLS effect in 1980 would be marginally significant. For example, the standard error for the estimated effect of cumulative teen fertility on high school graduation status is roughly .08. This is precise enough to detect high school graduation effects only slightly larger than the OLS estimate of .134 in a 5 percent test and just large enough to detect such effects in a 10 percent test. Thus, when applied in the stacked data, the instrumental variables procedure used here has the power to detect effects roughly the size of the OLS effects, although smaller effects probably would not be detected. Note that allowing the exposure effects in the first stage to differ by numbers of years of exposure or by the severity of state reforms (columns b and c) does not add appreciably to the precision of the IV estimates in Table 7.

\section{SUMMARY AND CONCLUSIONS}

This paper examines the fertility, marriage, schooling, and labor market outcomes of cohorts of women who were teenagers at the time states began to liberalize abortion laws. Reduced-form results from the 1980 Census show a large, statistically significant, and robust association between exposure to a liberalized abortion environment and a reduction in teen and out-of-wedlock childbearing for black women born 1949-54. These are the cohorts of women who were exposed as teenagers to the 1970 state abortion reforms in reform states. White women born 1949-54 also appear to have experienced a modest reduction in teen fertility, along with a sharp reduction in teen marriage rates. On the other hand, there is no evidence that national abortion liberalization affected the teen or out-of-wedlock fertility of women who were teenagers in 1973.

Overall, the results suggest that the first-stage teen marriage effects experienced by white women born 1949-54 did not generate detectable schooling or labor market consequences. In contrast, the teen fertility consequences of abortion reform for black women translated into large and statistically significant increases in high school graduation rates, college attendance rates, and 
employment rates. The causal interpretation of these findings is supported by the fact that, in the samples analyzed here, there is little association between our measure of abortion reform and the schooling or labor market outcomes of black men.

The evidence presented here is not seamless. For example, there is an unexplained association between abortion reform and the earnings of white men. On balance, however, we feel the results support the conclusion that black women benefitted from the liberalization of abortion policy. In particular, the reduction in teen and out-of-wedlock childbearing generated by liberalized abortion probably led to increased schooling and employment rates. On the other hand, the increase in schooling for black women is not reflected in the earnings of women who work. These findings naturally raise the question of why there is no evidence of an increase in earnings if abortion reform ultimately affected schooling. A likely answer is that effects on earnings are too far down the "causal chain" that began with abortion reform in 1970. The estimates in Table 5 suggest the impact of exposure on schooling can be summarized as raising average schooling by .0504 years. Assuming that this is the only reason why exposure affected schooling and that black women experience a 10 percent rate of return for each year of schooling, the expected impact of exposure on log wages would be .005 . Clearly such an effect cannot be detected given the standard error associated with reduced-form estimates of the impact of exposure on log wages (.0147 in Table 5).

One lesson from this study is that estimates of the effects of teen and out-of-wedlock childbearing that are both credible and precise are difficult to obtain from natural variation. This difficulty partly accounts for the lack of consensus among social scientists over the consequences of teen and out-of-wedlock childbearing. State abortion reform induced significant changes in teen fertility among black women, reducing the number of teen births by $8-10$ percent and the probability of having an out-of-wedlock teen birth by roughly 12 percent (averaging the reduced-form coefficients in Table 3 and comparing to the means). We are not aware of a social program targeted at teen and 
out-of-wedlock childbearing that has had as large an impact. Yet the consequences of this substantial variation are frustratingly difficult to measure, even with large Census samples. This suggests that future work should focus on isolating new sources of exogenous variation in fertility, as well as new sources of data, that can be combined to generate more precise estimates of the effects of teen and out-of-wedlock childbearing. 


\section{APPENDIX A: DATA}

1. Linking information on children and mothers in the 1980 Census.

Children were matched to mothers using the primary relationship code and detailed relationship codes reported in the person records of the 1980 PUMS. These codes show how each individual in the household is related to the person identified as the householder. In most cases, the mother/child match is straightforward. For example, if a woman in our sample (born 1949-59) who reported having given birth was designated as the householder or the spouse of another householder, we attached all people in the household labeled as "child" in the primary relationship code to this woman.

In households with multiple families, the match is more complicated. In this case, we used the detailed relationship codes as well as subfamily numbers to pair children with mothers. If a women who reported having given birth was a child of the householder, we attached all grandchildren of the householder sharing the same subfamily codes to the woman who reported having a child, identifying her as the mother.

The number of children attached to the mother is sometimes smaller than the number of reported births because not all children live with their mother, or because of the death of a child. Likewise, the number of children matched to a mother may exceed the number of reported births because the 1980 PUMS does not identify adopted children or step-children. For $93 \%$ of mothers in our sample, the self-reports of children ever born (CEB) was the same as our count of children born to the mother (KIDS). But we miss a larger fraction of births than 7 percent because the mothers for whom KIDS and CEB did not agree have more children (on average) than the mothers for whom KIDS and CEB did match. When the number of children ever born was zero, we assigned KIDS $=0$ regardless of the number of children observed in the household. 


\section{Comparing Census Data and Vital Statistics}

As noted in the text, Figures 1-3 compare fertility estimates from the 1980 Census to estimates published in National Center for Health Statistics (various years, [a]) natality data. NCHS natality data are derived from a census of birth records from about half the states and from samples of birth records from the remaining states. The two sources are combined to produce national estimates of birth rates (births per 1000 women) by cohort, calendar year, parity, and race. The NCHS natality statistics define a year-of-birth cohort as all women whose birthdays are within 6 months (before or after) of January 1 in that year. For example, women in the 1950 cohort were born between the dates July 1, 1949 and June 30, 1950.

For each cohort, natality statistics report the cumulative birth rate through December $31,1979$. To produce numbers comparable to the 1980 Census, we grouped women from the Census into birth cohorts (centered as in the natality data) deleting all births to women in the first quarter of 1980 , and summing all reported births. A comparison of teen birth measures requires more work. First, we obtained estimates of the percent of teen mothers in a cohort from natality data by summing the parity-one birth rates for a cohort through age 19. It should be noted that because natality-data births

are reported by calendar year and natality-data cohorts span years, this measure includes women up to 20.5 years old. Therefore, the natality and census measures of teen birth rates are not directly comparable. To improve comparability, we used the census to calculate the percent of women who had a first birth through the fourth quarter of the calendar year when the relevant cohort turned 19 (i.e., not using the individual mother's quarters of birth to date teenage years). For example, for the 1950 birth cohort, teen mothers were defined in the census data as those who gave birth before December 31, 1969. Similar procedures were used to compute cumulative teen birth rates (i.e., number of children born by age 20 ) from the two sources. 


\section{APPENDIX B: ESTIMATES USING ALTERNATE STATE GROUPINGS}

\section{No border states}

The precision of reduced-form estimates may be reduced because of movement between reform and non-reform states. During the reform period, many of the abortions performed in states where abortion was newly legalized were provided to women from out of state, and especially to women from neighboring states (see, e.g., Sklar and Berkov, 1974). In an effort to sharpen the contrast between reform and non-reform states, we analyzed samples that exclude 21 non-reform states bordering on reform states. The excluded states are Arizona, Connecticut, District of Columbia, Georgia, Idaho, Kentucky, Louisiana, Massachusetts, Mississippi, Missouri, Nebraska, Nevada, New Jersey, Oklahoma, Pennsylvania, Tennessee, Texas, Utah, Vermont, West Virginia, and Wyoming.

Table B1 reports estimates from models using alternative sets of state groups in 1980 data.

The columns labelled All States report results comparable to those discussed in the body of the paper, with the modification that the 3 exposure dummies are collapsed into a single dummy for exposure $>0$. As before, the models used to construct these estimates include a full set of state-ofbirth and year-of-birth effects. The columns labelled No Border States report corresponding results when border states are excluded. In practice, these estimates are similar to the results using all states, with somewhat larger standard errors.

\section{Matched-pairs of states}

The second alternate estimation strategy matches reform and non-reform states in an attempt to reduce between-state differences in the outcomes of pre-reform cohorts. Loosely speaking, reform and non-reform states may be more comparable once pre-reform differences in outcomes have been eliminated. This approach is similar in spirit to the strategy of matching on employment histories 
used by Card and Sullivan (1988) to evaluate manpower training. Although there is no time series dimension to Census data sets, the natural analog of pre-program outcomes for an analysis of abortion reform are the outcomes of women who are too old to have been affected during their teen years.

To justify this matching idea formally, suppose that cohort $c^{*}$ was the first to be affected by abortion reform in the reform states. When exposure is defined as years of exposure at ages 15-19 and reforms are dated as starting in $1971, \mathrm{c}^{*}=1952$. Consider the following modified version of equation 1 (the subscript $\mathrm{j}$ for outcomes is dropped):

$$
\begin{aligned}
& y_{1}=\sum_{c} \sum_{s} f_{i s} d_{i c} \alpha_{s}(c)+\sum_{c} d_{i c} \delta_{c}+\sum_{s} f_{i s} \phi_{s}+\sum_{p} e_{i p} \beta_{p}+\eta_{i} \\
& \alpha_{s}(c)=g\left(E_{s c^{*}-2}, F_{s c^{*}-2}\right),
\end{aligned}
$$

where $E_{\mathrm{sc}^{*}-2}$ is average schooling for cohort $c^{*}-2$ in state $s$ and $\mathrm{F}_{\mathrm{sc}^{*}-2}$ is average fertility for cohort $c^{*}-2$ in state s. $\alpha_{s}(\mathrm{c})$ is a state-specific cohort trend that is assumed to be the same in states where the average schooling and fertility of older cohorts $\left(\mathrm{E}_{\mathrm{sc}^{*}-2}, \mathrm{~F}_{\mathrm{sc}^{*}-2}\right)$ are the same. The term $\alpha_{\mathrm{s}}(\mathrm{c})$ is introduced in the outcome equation because of the possibility that reform states are characterized by different cohort trends than non-reform states. When $g\left(\mathrm{E}_{\mathrm{sc}^{*}-2}, \mathrm{~F}_{\mathrm{sc}^{*}-2}\right)$ is an unrestricted function of $\mathrm{E}_{\mathrm{sc}^{*}-2}$ and $\mathrm{F}_{\mathrm{sc}^{*}-2}$, equation (B.1) leads to an estimation strategy where every reform state is paired with one or more non-reform states having similar average schooling and fertility levels in the 1949-50 cohorts. This pairing controls for $\alpha_{\mathrm{s}}(\mathrm{c})$.

Note that when states are matched on variables for the 1949-50 cohorts, women from these cohorts should be excluded when estimating equation (B.1), otherwise the average dependent variable will implicitly be included as regressor in equation (B.1). Note also that even after matching and discarding observations on the 1949-50 cohorts, a state effect can still be included in a model for 1951 and younger cohorts because there is post-reform variation in $e_{i p}$ and because observations for $c^{*}-1$ are still available.

To implement the matching procedure, we first computed the average years of schooling and 
number of children ever born for each state (using the 1980 data). We then matched the states by quintile of the distribution of average schooling and CEB (separately by race) so as to minimize differences in fertility and schooling between reform and non-reform states for older cohorts. This match potentially generates up to 25 groups of states. Table $\mathrm{B} 2$ reports the list of reform and control states generated by the quintile match. In practice, the match produced 8 groups of reform and nonreform states for whites and 6 groups of reform and non-reform states for blacks, excluding quintile groups that are composed of either all reform or all non-reform states. For example, for whites, the reform state South Carolina is matched to the non-reform states Georgia and Tennessee. All three of these states are in the first quintile for the average years of schooling and the third quintile for the average fertility of women born 1949-50.

One way to use matched groups of reform and non-reform states is to estimate exposure effects separately in each group of states and then average the estimates. An alternative direct approach is to introduce a separate cohort effect for each quintile pair (i.e., a unique combination of education and fertility quintiles) in pooled estimation. In either case, groups consisting solely of reform or solely of non-reform states do not contribute to the estimates of exposure effects. Mixed reform/non-reform groups ( 8 for whites and 6 for nonwhites) contribute within-group variation.

The columns labelled State Matching in Table B1 report results from the state-matching strategy, computed using the regression approach described above. The results tend to be imprecise, although they support the basic findings of an increase in schooling and employment rates for black women. A few noteworthy differences between the state-matching results and the results in Table 3 are discussed in the text. 


\section{References}

Angrist, J.D. (1995), “Using Social Security Data to Estimate the Effect of Voluntary Military Service on Earnings," NBER Working Paper No. 5192, July.

Angrist, J.D., and G.W. Imbens, (1995), "Two-Stage Least Squares Estimates of Average Causal Response in Models with Variable Treatment Intensity," Journal of the American Statistical Association, June 1995.

Angrist, J.D., G.W. Imbens, and D.B. Rubin (1996), "Identification of Causal Effects Using Instrumental Variables," forthcoming, Journal of the American Statistical Association.

Angrist, J.D., and A.B. Krueger (1991), "Does Compulsory School Attendance Affect Schooling and Earnings?," Quarterly Journal of Economics, September 1991.

Angrist, J.D., and A.B. Krueger (1994), "Why Do World War Two Veterans Earn More than Nonveterans?," Journal of Labor Economics, January.

Angrist, J.D., and A.B. Krueger (1995), "Split-Sample Instrumental Variables Estimates of the Returns to Schooling," Journal of Business and Economic Statistics, April.

Bauman, K.E., A.E., Anderson, J.L. Freeman, and G.C. Koch (1977), "Legal Abortions, Subsidized Family Planning Services, and the US 'Birth Dearth'," Social Biology 24, 183-191.

Berkov, J., and B. Sklar (1974), "Abortion, Illegitimacy, and the American Birth Rate," Science 185 (September),909-915.

Blank, R.M., C.C. George, and R.A. London (1994), "State Abortion Rates: The Impact of Policies, Providers, Politics, Demographics, and Economic Environment," NBER Working Paper No. 4853.

Bronars, S.G., and J. Grogger (1994), "The Economic Consequences of Unwed Motherhood: Using Twin Births as a Natural Experiment." American Economic Review, 84, 1141-1156.

Bureau of the Census (1983), Census of Population and Housing, 1980: Public Use Microdata Sample A, Washington, DC, Bureau of the Census.

Bureau of the Census (1993), Census of Population and Housing, 1990: Public Use Microdata Sample A, Washington, DC, Bureau of the Census (distributed on CD-ROM).

Cairns, R.B., B.D. Cairns, and H.J.Neckerman (1989), "Early School Dropout: Configurations and Determinants," Child Development 60, 1437-1452.

Card, J.J., and Wise, L.L. (1978), "Teenage Mothers and Teenage Fathers: The Impact of Early Childbearing on the Parent's Personal and Professional Lives." Family Planning Perspectives, 10, 199-205.

Card, D.E., and A. Krueger (1992), "Does School Quality Matter? Returns to Education and the Characteristics of Public Schools in the United States," Journal of Political Economy, February 1992.

Card, D.E., and D. Sullivan (1988), "The Effect of Subsidized Training on Movements in and Out of Employment," Econometrica 56, 497-530.

Centers for Disease Control (1974), Abortion Surveillance Report, Legal Abortions, United States, Annual Summaries. Atlanta: Department of Health, Education, and Welfare.

Currie, J., L. Nixon, and N. Cole (1993), "Restrictions on Medicaid Funding of Abortion: Effects on Pregnancy Resolutions and Birth Weight," NBER Working Paper No. 4432.

Furstenberg, F. (1976), Unplanned Parenthood, New York: Free Press.

Furstenberg, F., J. Brooks-Gunn, P. Morgan (1987), Adolescent Mothers Later in Life, , Cambridge, MA: Cambridge University Press.

Garfinkle, I., and S. McLanahan (1986), Single Mothers and their Children: A New American Dilemma. Washington, DC: Urban Institute.

Geronimus, A.T., and S. Korenman (1992), "The Socioeconomic Consequences of Teen Childbearing Reconsidered," Quarterly Journal of Economics, 107, 1187-1214. 
Geronimus, A.T., and S. Korenman (1993), "The Costs of Teenage Childbearing: Evidence and Interpretation," Demography, 30, 281-290.

Hofferth, S. (1987), "Social and Economic Consequences of Teenage Childbearing," in S. Hofferth and C. D. Hayes, eds., Risking the Future: Adolescent Sexuality, Pregnancy, and Childbearing, Vol. II., Washington, DC: National Academy of Sciences, 123-144.

Hofferth, S., and K. Moore (1979), "Early Childbearing and Later Economic Well-Being." American Sociological Review, 44, 784-815.

Hotz, J., S. McElroy, and S. Sanders (1995), "Assessing the Effects of Teenage Childbearing on Maternal Outcomes in the United States: Exploiting a Very Natural Experiment," University of Chicago, Harris School of Public Policy, mimeo, August.

Imbens, G.W., and van der Klauww (1995), "The Cost of Conscription in the Netherlands," Journal of Business and Economic Statistics 13, April.

Joyce, T., and M. Grossman (1993), "Pregnancy Wantedness and the Early Initiation of Prenatal Care," Demography, 27, 1-17.

Joyce, T. and Mocan (1990), "The Impact of Legalized Abortion on Adolescent Childbearing in New York City," American Journal of Public Health 80, 273-278.

Levine, P.B., A.B. Trainor, and D. Zimmerman (1995), "The Effect of Medicaid Abortion Funding Restrictions on Abortions, Pregnancies, and Births," Wellesley College Department of Economics, mimeo, January.

Levine, P.B., T.J. Kane, D. Staiger, and D. Zimmerman (1995), "Roe V. Wade and American Fertility," Wellesley College Department of Economics, mimeo, January.

Lundberg, S., and R. Plotnick (1990), "Effects of State Welfare, Abortion and Family Planning Policies on Premarital Childbearing among White Adolescents," Family Planning Perspectives, 22, 246-251, 275.

McCarthy, P.J. (1979), "Some Sources of Error in Labor Force Estimates from the Current Population Survey," pp. 1-40 in National Commission on Employment and Unemployment Statistics, Counting the Labor Forces, Appendix Volume II, Washington, DC: US GPO.

McLanahan, S., and G. Sandefur, (1994), "Growing Up with a Single Parent: What Hurts, What Helps, Cambridge: Harvard University Press.

Mott, F., and M. William (1985), "Early Childbearing and Completion of High School," Family Planning Perspectives, 17, 234-237.

National Center for Health Statistics (various years, [a]), Vital Statistics of the United States: Natality, Hyattsville, Md.: US Department of Health and Human Services.

National Center for Health Statistics (various years, [b]), Vital Statistics of the United States: Marriage and Divorce, Hyattsville, Md.: US Department of Health and Human Services.

Olsen, R., and G. Farkas (1989), "Endogenous Covariates in Duration Models and the Effect of Adolescent Childbirth on Schooling," Journal of Human Resources, 24, 37-53.

Ribar, S. (1994), "Teen Births and High School Graduation," Review of Economics and Statistics, August 1994.

Sklar, J., and B. Berkov (1974), “Abortion, Illegitimacy, and the American Birth Rate," Science 13, pp. 909915.

Trussell, J.T. (1976), "The Economic Consequences of Teenage Childbearing. " Family Planning Perspectives, 8, 184-190.

Upchurch, D., and J. McCarthy (1990), "The Timing of First Birth and High School Completion," American Sociological Review, 55, 224-234. 
Table 1

Period-cohort diagram

Years of exposure Years of exposure

at age 15-19, at age 15-19,

Calendar Year

reforms in 70,73

Age of

first

exposure,

reform in

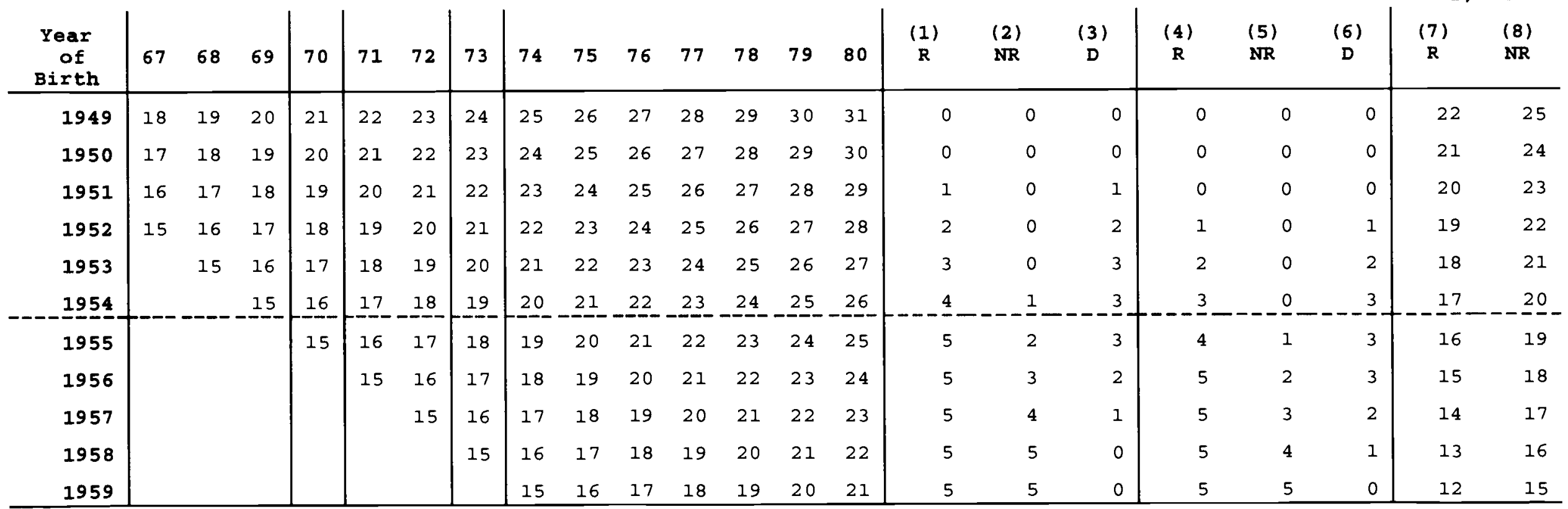

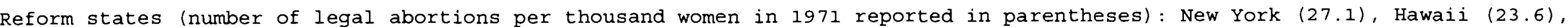

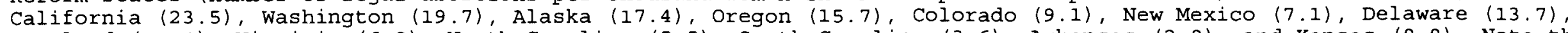

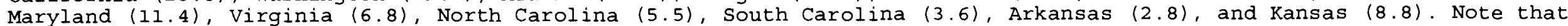
exposure at ages 15-19 in 1971 and 1974 is the same as exposure at ages $14-18$ in 1970 and 1973 . 
Table 2

Impact of Teen Motherhood on Early Economic Outcomes

1980 Census PUMS

1949-1959 Birth Cohorts

\begin{tabular}{|c|c|c|c|c|c|c|c|c|c|}
\hline & \multirow[b]{3}{*}{ Regressor } & \multicolumn{4}{|c|}{ 1949-1954 Birth cohorts } & \multicolumn{4}{|c|}{ 1955-1959 Birth cohorts } \\
\hline & & \multirow[b]{2}{*}{ Mean } & \multicolumn{3}{|c|}{ OLS estimates and standard errors } & \multirow[b]{2}{*}{ Mean } & \multicolumn{3}{|c|}{ OLS estimates and standard errors } \\
\hline & & & $\begin{array}{l}\text { High } \\
\text { school } \\
\text { graduate }\end{array}$ & $\begin{array}{l}\text { College } \\
\text { entrant }\end{array}$ & $\begin{array}{l}\text { In } \\
\text { poverty }\end{array}$ & & $\begin{array}{l}\text { High } \\
\text { school } \\
\text { graduate }\end{array}$ & $\begin{array}{l}\text { College } \\
\text { entrant }\end{array}$ & $\begin{array}{l}\text { In } \\
\text { poverty }\end{array}$ \\
\hline \multirow[t]{6}{*}{ Whites } & & \multicolumn{4}{|c|}{ (420,920 observations) } & \multicolumn{4}{|c|}{ ( 375,417 observations) } \\
\hline & Teen mother & 0.189 & $\begin{array}{l}-0.255 \\
(0.001)\end{array}$ & $\begin{array}{l}-0.401 \\
(0.002)\end{array}$ & $\begin{array}{c}0.077 \\
(0.001)\end{array}$ & 0.161 & $\begin{array}{l}-0.326 \\
(0.001)\end{array}$ & $\begin{array}{l}-0.419 \\
(0.002)\end{array}$ & $\begin{array}{c}0.084 \\
(0.001)\end{array}$ \\
\hline & $\begin{array}{l}\text { Children before } \\
\text { age } 20 \\
\left(K^{\prime} B 20 \_A\right)\end{array}$ & 0.231 & $\begin{array}{l}-0.211 \\
(0.001)\end{array}$ & $\begin{array}{l}-0.283 \\
(0.001)\end{array}$ & $\begin{array}{c}0.064 \\
(0.001)\end{array}$ & 0.195 & $\begin{array}{l}-0.265 \\
(0.001)\end{array}$ & $\begin{array}{l}-0.300 \\
(0.002)\end{array}$ & $\begin{array}{c}0.075 \\
(0.001)\end{array}$ \\
\hline & $\begin{array}{l}\text { Teen out of } \\
\text { wedlock birth }\end{array}$ & 0.033 & $\begin{array}{l}-0.236 \\
(0.003)\end{array}$ & $\begin{array}{l}-0.306 \\
(0.004)\end{array}$ & $\begin{array}{c}0.108 \\
(0.002)\end{array}$ & 0.034 & $\begin{array}{l}-0.333 \\
(0.003)\end{array}$ & $\begin{array}{l}-0.356 \\
(0.004)\end{array}$ & $\begin{array}{c}0.163 \\
(0.003)\end{array}$ \\
\hline & $\begin{array}{l}\text { Married before } \\
\text { age } 20\end{array}$ & 0.555 & $\begin{array}{l}-0.085 \\
(0.001)\end{array}$ & $\begin{array}{l}-0.200 \\
(0.002)\end{array}$ & $\begin{array}{c}0.007 \\
(0.001)\end{array}$ & 0.468 & $\begin{array}{l}-0.120 \\
(0.001)\end{array}$ & $\begin{array}{l}-0.301 \\
(0.002)\end{array}$ & $\begin{array}{l}-0.044 \\
(0.001)\end{array}$ \\
\hline & Mean & & 0.884 & 0.457 & 0.083 & & 0.868 & 0.426 & 0.124 \\
\hline \multirow[t]{6}{*}{ Blacks } & & \multicolumn{4}{|c|}{ ( 61,778 observations) } & \multicolumn{4}{|c|}{$(58,947$ observations $)$} \\
\hline & Teen mother & 0.397 & $\begin{array}{l}-0.202 \\
(0.003)\end{array}$ & $\begin{array}{l}-0.247 \\
(0.004)\end{array}$ & $\begin{array}{c}0.183 \\
(0.004)\end{array}$ & 0.335 & $\begin{array}{l}-0.231 \\
(0.004)\end{array}$ & $\begin{array}{l}-0.295 \\
(0.004)\end{array}$ & $\begin{array}{c}0.218 \\
(0.004)\end{array}$ \\
\hline & $\begin{array}{l}\text { Children before } \\
\text { age } 20 \\
\text { (KB20_A) }\end{array}$ & 0.563 & $\begin{array}{l}-0.155 \\
(0.002)\end{array}$ & $\begin{array}{l}-0.146 \\
(0.002)\end{array}$ & $\begin{array}{c}0.127 \\
(0.002)\end{array}$ & 0.457 & $\begin{array}{c}-0.174 \\
(0.002)\end{array}$ & $\begin{array}{l}-0.179 \\
(0.003)\end{array}$ & $\begin{array}{c}0.151 \\
(0.003)\end{array}$ \\
\hline & $\begin{array}{l}\text { Teen out -of- } \\
\text { wedlock birth }\end{array}$ & 0.251 & $\begin{array}{l}-0.185 \\
(0.004)\end{array}$ & $\begin{array}{l}-0.205 \\
(0.004)\end{array}$ & $\begin{array}{c}0.187 \\
(0.004)\end{array}$ & 0.253 & $\begin{array}{l}-0.214 \\
(0.004)\end{array}$ & $\begin{array}{l}-0.258 \\
(0.004)\end{array}$ & $\begin{array}{c}0.245 \\
(0.004)\end{array}$ \\
\hline & $\begin{array}{l}\text { Married before } \\
\text { age } 20\end{array}$ & 0.399 & $\begin{array}{l}-0.061 \\
(0.003)\end{array}$ & $\begin{array}{l}-0.092 \\
(0.004)\end{array}$ & $\begin{array}{l}-0.016 \\
(0.004)\end{array}$ & 0.261 & $\begin{array}{l}-0.057 \\
(0.003)\end{array}$ & $\begin{array}{l}-0.091 \\
(0.004)\end{array}$ & $\begin{array}{l}-0.023 \\
(0.003)\end{array}$ \\
\hline & Mean & & 0.768 & 0.342 & 0.269 & & 0.772 & 0.352 & 0.317 \\
\hline
\end{tabular}

The sample is described in the text. The table reports OLS estimates of the effect of variables in the regressor column on high school graduation, college entrance, and poverty status. All models include state of birth and year of birth fixed-effects. 
Table 3

Least-Square Estimates, First and Second Stage Outcomes

1949-1954 Birth Cohorts

1980 Census PUMS

by Sex and Race

\begin{tabular}{|c|c|c|c|c|c|c|c|c|c|c|c|}
\hline \multirow[b]{3}{*}{ First-stage outcomes } & \multirow[b]{3}{*}{ Sample } & \multicolumn{5}{|c|}{$\begin{array}{c}\text { Whites } \\
(420,920 \text { observations for women, } 417,812 \text { for men })\end{array}$} & \multirow[b]{3}{*}{ Mean } & \multicolumn{4}{|c|}{$\begin{array}{c}\text { Blacks } \\
(61,778 \text { observations for women, } 51,371 \text { for men })\end{array}$} \\
\hline & & \multirow[b]{2}{*}{ Mean } & \multicolumn{3}{|c|}{ Years of exposure } & \multirow[b]{2}{*}{$\begin{array}{l}\text { f-test } \\
\text { (p value) }\end{array}$} & & & ars of exp & & \multirow[b]{2}{*}{$\begin{array}{l}f-\text { test } \\
\text { ( } p \text { value) }\end{array}$} \\
\hline & & & 1 & 2 & 3 & & & 1 & 2 & 3 & \\
\hline $\begin{array}{l}\text { Children born before } \\
\text { age } 20\left(\mathrm{~KB} 20 \_\mathrm{A}\right)\end{array}$ & women & 0.231 & $\begin{array}{c}0.003 \\
(0.005)\end{array}$ & $\begin{array}{c}0.003 \\
(0.005)\end{array}$ & $\begin{array}{l}-0.011 \\
(0.005)\end{array}$ & $\begin{array}{c}2.59 \\
(0.05)\end{array}$ & 0.564 & $\begin{array}{l}-0.040 \\
(0.020)\end{array}$ & $\begin{array}{l}-0.051 \\
(0.020)\end{array}$ & $\begin{array}{l}-0.056 \\
(0.019)\end{array}$ & $\begin{array}{c}4.24 \\
(0.01)\end{array}$ \\
\hline $\begin{array}{l}\text { Children born before } \\
\text { age } 20 \text { (KB20_B) }\end{array}$ & women & 0.310 & $\begin{array}{l}-0.001 \\
(0.006)\end{array}$ & $\begin{array}{l}-0.003 \\
(0.006)\end{array}$ & $\begin{array}{l}-0.016 \\
(0.006)\end{array}$ & $\begin{array}{c}2.42 \\
(0.06)\end{array}$ & 0.796 & $\begin{array}{l}-0.048 \\
(0.025)\end{array}$ & $\begin{array}{l}-0.066 \\
(0.025)\end{array}$ & $\begin{array}{l}-0.068 \\
(0.025)\end{array}$ & $\begin{array}{l}4.06 \\
(0.01)\end{array}$ \\
\hline Teen mother & women & 0.189 & $\begin{array}{l}-0.002 \\
(0.004)\end{array}$ & $\begin{array}{l}-0.001 \\
(0.004)\end{array}$ & $\begin{array}{l}-0.012 \\
(0.004)\end{array}$ & $\begin{array}{c}3.79 \\
(0.01)\end{array}$ & 0.397 & $\begin{array}{l}-0.027 \\
(0.012)\end{array}$ & $\begin{array}{l}-0.024 \\
(0.012)\end{array}$ & $\begin{array}{l}-0.045 \\
(0.012)\end{array}$ & $\begin{array}{c}5.73 \\
(0.00)\end{array}$ \\
\hline $\begin{array}{l}\text { Teen out-of-wedlock } \\
\text { birth }\end{array}$ & women & 0.033 & $\begin{array}{c}0.002 \\
(0.002)\end{array}$ & $\begin{array}{l}-0.000 \\
(0.002)\end{array}$ & $\begin{array}{c}0.001 \\
(0.002)\end{array}$ & $\begin{array}{c}0.38 \\
(0.77)\end{array}$ & 0.251 & $\begin{array}{l}-0.021 \\
(0.010)\end{array}$ & $\begin{array}{l}-0.021 \\
(0.011)\end{array}$ & $\begin{array}{l}-0.045 \\
(0.010)\end{array}$ & $\begin{array}{c}6.72 \\
(0.00)\end{array}$ \\
\hline \multirow[t]{2}{*}{$\begin{array}{l}\text { Married before age } \\
20\end{array}$} & women & 0.56 & $\begin{array}{l}-0.005 \\
(0.005)\end{array}$ & $\begin{array}{l}-0.014 \\
(0.005)\end{array}$ & $\begin{array}{l}-0.029 \\
(0.004)\end{array}$ & $\begin{array}{l}13.88 \\
(0.00)\end{array}$ & 0.399 & $\begin{array}{l}-0.027 \\
(0.012)\end{array}$ & $\begin{array}{l}-0.023 \\
(0.012)\end{array}$ & $\begin{array}{l}-0.012 \\
(0.012)\end{array}$ & $\begin{array}{c}2.47 \\
(0.06)\end{array}$ \\
\hline & men & 0.16 & $\begin{array}{l}-0.008 \\
(0.003)\end{array}$ & $\begin{array}{l}-0.006 \\
(0.003)\end{array}$ & $\begin{array}{l}-0.008 \\
(0.003)\end{array}$ & $\begin{array}{l}2.51 \\
(0.06)\end{array}$ & 0.136 & $\begin{array}{l}-0.011 \\
(0.009)\end{array}$ & $\begin{array}{l}-0.007 \\
(0.009)\end{array}$ & $\begin{array}{c}0.002 \\
(0.009)\end{array}$ & $\begin{array}{c}0.69 \\
(0.57)\end{array}$ \\
\hline
\end{tabular}


Table 3 (continued)

\begin{tabular}{|c|c|c|c|c|c|c|c|c|c|c|c|}
\hline Second-stage outcomes & & & & & & & & & & & \\
\hline \multirow[t]{2}{*}{ High school graduate } & women & 0.884 & $\begin{array}{l}-0.006 \\
(0.003)\end{array}$ & $\begin{array}{l}-0.002 \\
(0.003)\end{array}$ & $\begin{array}{l}-0.003 \\
(0.003)\end{array}$ & $\begin{array}{c}1.51 \\
(0.21)\end{array}$ & 0.768 & $\begin{array}{c}0.006 \\
(0.010)\end{array}$ & $\begin{array}{c}0.031 \\
(0.010)\end{array}$ & $\begin{array}{c}0.005 \\
(0.010)\end{array}$ & $\begin{array}{c}3.16 \\
(0.02)\end{array}$ \\
\hline & men & 0.884 & $\begin{array}{l}-0.002 \\
(0.003)\end{array}$ & $\begin{array}{c}0.000 \\
(0.003)\end{array}$ & $\begin{array}{l}-0.002 \\
(0.003)\end{array}$ & $\begin{array}{c}0.25 \\
(0.86)\end{array}$ & 0.745 & $\begin{array}{c}0.008 \\
(0.012)\end{array}$ & $\begin{array}{c}0.007 \\
(0.012)\end{array}$ & $\begin{array}{c}0.010 \\
(0.011)\end{array}$ & $\begin{array}{c}0.38 \\
(0.77)\end{array}$ \\
\hline \multirow[t]{2}{*}{ College entrant } & women & 0.458 & $\begin{array}{c}0.000 \\
(0.005)\end{array}$ & $\begin{array}{l}-0.006 \\
(0.005)\end{array}$ & $\begin{array}{l}-0.000 \\
(0.005)\end{array}$ & $\begin{array}{c}0.67 \\
(0.57)\end{array}$ & 0.346 & $\begin{array}{c}0.023 \\
(0.011)\end{array}$ & $\begin{array}{c}0.008 \\
(0.011)\end{array}$ & $\begin{array}{c}0.017 \\
(0.011)\end{array}$ & $\begin{array}{c}1.72 \\
(0.16)\end{array}$ \\
\hline & men & 0.522 & $\begin{array}{c}0.002 \\
(0.005)\end{array}$ & $\begin{array}{c}0.006 \\
(0.005)\end{array}$ & $\begin{array}{l}-0.001 \\
(0.005)\end{array}$ & $\begin{array}{c}0.62 \\
(0.60)\end{array}$ & 0.336 & $\begin{array}{c}0.007 \\
(0.012)\end{array}$ & $\begin{array}{c}0.001 \\
(0.012)\end{array}$ & $\begin{array}{c}0.012 \\
(0.012)\end{array}$ & $\begin{array}{c}0.37 \\
(0.77)\end{array}$ \\
\hline \multirow[t]{2}{*}{ Worked } & women & 0.710 & $\begin{array}{c}0.002 \\
(0.004)\end{array}$ & $\begin{array}{c}0.007 \\
(0.004)\end{array}$ & $\begin{array}{r}-0.002 \\
(0.004)\end{array}$ & $\begin{array}{c}1.26 \\
(0.29)\end{array}$ & 0.722 & $\begin{array}{c}0.000 \\
(0.011)\end{array}$ & $\begin{array}{c}0.031 \\
(0.011)\end{array}$ & $\begin{array}{c}0.014 \\
(0.011)\end{array}$ & $\begin{array}{c}3.04 \\
(0.03)\end{array}$ \\
\hline & men & 0.906 & $\begin{array}{r}-0.003 \\
(0.003)\end{array}$ & $\begin{array}{l}-0.000 \\
(0.003)\end{array}$ & $\begin{array}{c}0.001 \\
(0.003)\end{array}$ & $\begin{array}{c}0.34 \\
(0.80)\end{array}$ & 0.834 & $\begin{array}{c}0.006 \\
(0.010)\end{array}$ & $\begin{array}{c}0.006 \\
(0.010)\end{array}$ & $\begin{array}{c}0.012 \\
(0.010)\end{array}$ & $\begin{array}{c}0.61 \\
(0.61)\end{array}$ \\
\hline \multirow[t]{2}{*}{ In poverty } & women & 0.083 & $\begin{array}{c}0.000 \\
(0.003)\end{array}$ & $\begin{array}{l}-0.001 \\
(0.003)\end{array}$ & $\begin{array}{c}0.004 \\
(0.003)\end{array}$ & $\begin{array}{c}0.88 \\
(0.45)\end{array}$ & 0.269 & $\begin{array}{c}0.004 \\
(0.011)\end{array}$ & $\begin{array}{c}0.001 \\
(0.011)\end{array}$ & $\begin{array}{l}-0.008 \\
(0.011)\end{array}$ & $\begin{array}{c}0.33 \\
(0.80)\end{array}$ \\
\hline & men & 0.058 & $\begin{array}{c}0.003 \\
(0.002)\end{array}$ & $\begin{array}{c}0.004 \\
(0.002)\end{array}$ & $\begin{array}{c}0.006 \\
(0.002)\end{array}$ & $\begin{array}{c}3.15 \\
(0.02)\end{array}$ & 0.142 & $\begin{array}{l}-0.006 \\
(0.009)\end{array}$ & $\begin{array}{c}0.001 \\
(0.009)\end{array}$ & $\begin{array}{l}-0.000 \\
(0.009)\end{array}$ & $\begin{array}{c}0.15 \\
(0.93)\end{array}$ \\
\hline
\end{tabular}

The table reports OLS estimates of the effect of years of exposure to abortion reform on a variety of outcome variables. The f-tests are for the joint significance of 3 years-of-exposure dummies. All models include year of birth effects and state of birth effects. 
Table 4: OLS Estimates, First and Second Stage Outcomes,

1949-1954 Birth Cohorts

1990 Census PUMS, by Sex, Race and Cohor

\begin{tabular}{|c|c|c|c|c|c|c|c|c|c|c|c|}
\hline \multirow[b]{3}{*}{ Outcomes } & \multirow[b]{3}{*}{ Sample } & \multicolumn{5}{|c|}{$\begin{array}{c}\text { Whites } \\
(445,402 \text { observations for women, } 428,205 \text { for men })\end{array}$} & \multicolumn{5}{|c|}{$\begin{array}{c}\text { Blacks } \\
\text { (54,314 observations for women, } 39,942 \text { for men) }\end{array}$} \\
\hline & & \multirow[b]{2}{*}{ Mean } & \multicolumn{3}{|c|}{ Years of exposure } & \multirow[b]{2}{*}{$\begin{array}{l}\text { f-test } \\
\text { ( } p \text { value) }\end{array}$} & \multirow[b]{2}{*}{ Mean } & \multicolumn{3}{|c|}{ Years of exposure } & \multirow[b]{2}{*}{$\begin{array}{l}\text { f-test } \\
\text { (p value) }\end{array}$} \\
\hline & & & 1 & 2 & 3 & & & 1.00 & 2 & 3 & \\
\hline Children ever born (CEB) & women & 1.788 & $\begin{array}{r}0.019 \\
(0.012)\end{array}$ & $\begin{array}{l}-0.001 \\
(0.012)\end{array}$ & $\begin{array}{c}0.006 \\
(0.012)\end{array}$ & $\begin{array}{c}1.01 \\
(0.39)\end{array}$ & 2.163 & $\begin{array}{c}0.026 \\
(0.041)\end{array}$ & $\begin{array}{c}0.047 \\
(0.040)\end{array}$ & $\begin{array}{l}-0.070 \\
(0.040)\end{array}$ & $\begin{array}{c}2.24 \\
(0.08)\end{array}$ \\
\hline \multirow[t]{2}{*}{ High school graduate } & women & 0.913 & $\begin{array}{r}-0.003 \\
(0.003)\end{array}$ & $\begin{array}{l}-0.001 \\
(0.003)\end{array}$ & $\begin{array}{l}-0.002 \\
(0.003)\end{array}$ & $\begin{array}{c}0.48 \\
(0.70)\end{array}$ & 0.799 & $\begin{array}{c}0.011 \\
(0.010)\end{array}$ & $\begin{array}{c}0.006 \\
(0.010)\end{array}$ & $\begin{array}{c}0.003 \\
(0.010)\end{array}$ & $\begin{array}{c}0.41 \\
(0.75)\end{array}$ \\
\hline & men & 0.905 & $\begin{array}{l}-0.005 \\
(0.003)\end{array}$ & $\begin{array}{l}-0.002 \\
(0.003)\end{array}$ & $\begin{array}{l}-0.003 \\
(0.003)\end{array}$ & $\begin{array}{c}1.01 \\
(0.39)\end{array}$ & 0.768 & $\begin{array}{c}0.010 \\
(0.013)\end{array}$ & $\begin{array}{l}-0.008 \\
(0.013)\end{array}$ & $\begin{array}{c}0.026 \\
(0.012)\end{array}$ & $\begin{array}{c}2.00 \\
(0.11)\end{array}$ \\
\hline \multirow[t]{2}{*}{ College entrant } & women & 0.602 & $\begin{array}{l}-0.008 \\
(0.005)\end{array}$ & $\begin{array}{l}-0.001 \\
(0.005)\end{array}$ & $\begin{array}{c}0.005 \\
(0.004)\end{array}$ & $\begin{array}{c}2.21 \\
(0.08)\end{array}$ & 0.484 & $\begin{array}{l}-0.006 \\
(0.013)\end{array}$ & $\begin{array}{c}0.017 \\
(0.013)\end{array}$ & $\begin{array}{c}0.030 \\
(0.013)\end{array}$ & $\begin{array}{c}2.63 \\
(0.05)\end{array}$ \\
\hline & men & 0.636 & $\begin{array}{c}0.004 \\
(0.005)\end{array}$ & $\begin{array}{c}0.004 \\
(0.005)\end{array}$ & $\begin{array}{c}0.011 \\
(0.004)\end{array}$ & $\begin{array}{c}2.04 \\
(0.11)\end{array}$ & 0.454 & $\begin{array}{c}0.037 \\
(0.015)\end{array}$ & $\begin{array}{l}-0.009 \\
(0.015)\end{array}$ & $\begin{array}{c}0.011 \\
(0.015)\end{array}$ & $\begin{array}{c}2.49 \\
(0.06)\end{array}$ \\
\hline \multirow[t]{2}{*}{ College graduate } & women & 0.270 & $\begin{array}{l}-0.000 \\
(0.004)\end{array}$ & $\begin{array}{c}0.006 \\
(0.004)\end{array}$ & $\begin{array}{c}0.008 \\
(0.004)\end{array}$ & $\begin{array}{c}1.78 \\
(0.15)\end{array}$ & 0.160 & $\begin{array}{c}0.001 \\
(0.010)\end{array}$ & $\begin{array}{c}0.011 \\
(0.009)\end{array}$ & $\begin{array}{c}0.014 \\
(0.009)\end{array}$ & $\begin{array}{c}1.06 \\
(0.36)\end{array}$ \\
\hline & men & 0.311 & $\begin{array}{l}-0.002 \\
(0.004)\end{array}$ & $\begin{array}{l}-0.000 \\
(0.004)\end{array}$ & $\begin{array}{c}0.001 \\
(0.004)\end{array}$ & $\begin{array}{c}0.06 \\
(0.98)\end{array}$ & 0.141 & $\begin{array}{c}0.010 \\
(0.011)\end{array}$ & $\begin{array}{c}0.011 \\
(0.011)\end{array}$ & $\begin{array}{c}-0.010 \\
(0.010)\end{array}$ & $\begin{array}{c}1.29 \\
(0.27)\end{array}$ \\
\hline \multirow[t]{2}{*}{ In poverty } & women & 0.071 & $\begin{array}{c}0.004 \\
(0.002)\end{array}$ & $\begin{array}{l}-0.004 \\
(0.002)\end{array}$ & $\begin{array}{l}-0.001 \\
(0.002)\end{array}$ & $\begin{array}{c}2.55 \\
(0.05)\end{array}$ & 0.242 & $\begin{array}{c}0.005 \\
(0.011)\end{array}$ & $\begin{array}{c}0.002 \\
(0.011)\end{array}$ & $\begin{array}{l}-0.013 \\
(0.011)\end{array}$ & $\begin{array}{c}0.77 \\
(0.51)\end{array}$ \\
\hline & men & 0.007 & $\begin{array}{l}-0.001 \\
(0.001)\end{array}$ & $\begin{array}{c}0.001 \\
(0.001)\end{array}$ & $\begin{array}{c}0.001 \\
(0.001)\end{array}$ & $\begin{array}{c}1.77 \\
(0.15)\end{array}$ & 0.021 & $\begin{array}{c}0.000 \\
(0.005)\end{array}$ & $\begin{array}{l}-0.005 \\
(0.004)\end{array}$ & $\begin{array}{l}-0.001 \\
(0.004)\end{array}$ & $\begin{array}{c}0.52 \\
(0.67)\end{array}$ \\
\hline \multirow[t]{2}{*}{ Worked } & women & 0.757 & $\begin{array}{l}-0.000 \\
(0.004)\end{array}$ & $\begin{array}{c}0.005 \\
(0.004)\end{array}$ & $\begin{array}{r}-0.001 \\
(0.004)\end{array}$ & $\begin{array}{c}0.56 \\
(0.64)\end{array}$ & 0.777 & $\begin{array}{c}0.003 \\
(0.011)\end{array}$ & $\begin{array}{c}0.008 \\
(0.011)\end{array}$ & $\begin{array}{c}0.014 \\
(0.011)\end{array}$ & $\begin{array}{c}0.62 \\
(0.60)\end{array}$ \\
\hline & men & 0.875 & $\begin{array}{c}0.001 \\
(0.003)\end{array}$ & $\begin{array}{c}0.001 \\
(0.003)\end{array}$ & $\begin{array}{l}-0.001 \\
(0.003)\end{array}$ & $\begin{array}{c}0.14 \\
(0.93)\end{array}$ & 0.805 & $\begin{array}{l}-0.023 \\
(0.012)\end{array}$ & $\begin{array}{l}-0.006 \\
(0.012)\end{array}$ & $\begin{array}{l}-0.013 \\
(0.012)\end{array}$ & $\begin{array}{c}1.29 \\
(0.28)\end{array}$ \\
\hline
\end{tabular}




\begin{tabular}{|c|c|c|c|c|c|c|c|c|c|c|c|}
\hline \multirow[t]{2}{*}{ Log labor earnings } & women & 9.406 & $\begin{array}{l}-0.019 \\
(0.012)\end{array}$ & $\begin{array}{l}-0.003 \\
(0.012)\end{array}$ & $\begin{array}{c}0.004 \\
(0.012)\end{array}$ & $\begin{array}{c}1.12 \\
(0.34)\end{array}$ & 9.471 & $\begin{array}{r}-0.023 \\
(0.029)\end{array}$ & $\begin{array}{l}-0.017 \\
(0.029)\end{array}$ & $\begin{array}{c}0.029 \\
(0.028)\end{array}$ & $\begin{array}{c}0.90 \\
(0.44)\end{array}$ \\
\hline & men & 10.19 & $\begin{array}{c}0.012 \\
(0.008)\end{array}$ & $\begin{array}{l}-0.013 \\
(0.008)\end{array}$ & $\begin{array}{l}-0.008 \\
(0.008)\end{array}$ & $\begin{array}{c}2.34 \\
(0.07)\end{array}$ & 9.716 & $\begin{array}{l}-0.013 \\
(0.034)\end{array}$ & $\begin{array}{l}-0.015 \\
(0.034)\end{array}$ & $\begin{array}{l}-0.034 \\
(0.033)\end{array}$ & $\begin{array}{c}0.35 \\
(0.79)\end{array}$ \\
\hline
\end{tabular}

The table reports OLS estimates of the effect of years of exposure to abortion reform on a variety of outcome variables. The f-tests are for the joint significance of 3 years-of-exposure dummies. All models include year of birth effects and state of birth effects. 
Table 5:

OLS Estimates, First and Second Stage Outcomes.

1949-1954 Birth Cohorts

1980 and 1990 Census PUMS, Stacked

by Sex and Race

\begin{tabular}{|c|c|c|c|c|c|c|c|}
\hline \multirow[b]{2}{*}{ Outcomes } & \multirow[b]{2}{*}{ Sample } & \multicolumn{3}{|c|}{$\begin{array}{c}\text { Whites } \\
(866,322 \text { observations for women, } \\
846,017 \text { for men) }\end{array}$} & \multicolumn{3}{|c|}{$\begin{array}{c}\text { Blacks } \\
\text { (116,092 observations for women, } \\
91,313 \text { for men) }\end{array}$} \\
\hline & & Mean & $\begin{array}{l}\text { Coefficient } \\
\text { on } \\
\text { exposure }>0\end{array}$ & $\begin{array}{l}\text { F-test ( } \mathrm{p} \text {-value) } \\
\text { on } 3 \text { exposure } \\
\text { indicators }\end{array}$ & Mean & $\begin{array}{l}\text { Coefficient } \\
\text { on } \\
\text { exposure }>0\end{array}$ & $\begin{array}{l}\text { F-test ( } \mathrm{p} \text {-value) } \\
\text { on } 3 \text { exposure } \\
\text { indicators }\end{array}$ \\
\hline Children ever born (CEB) & women & 1.499 & $\begin{array}{c}0.0095 \\
(0.0057)\end{array}$ & $\begin{array}{c}1.13 \\
(0.33)\end{array}$ & 1.921 & $\begin{array}{l}-0.0118 \\
(0.0185)\end{array}$ & $\begin{array}{c}1.70 \\
(0.16)\end{array}$ \\
\hline \multirow[t]{2}{*}{ High school graduate } & women & 0.899 & $\begin{array}{l}-0.0028 \\
(0.0014)\end{array}$ & $\begin{array}{c}1.87 \\
(0.13)\end{array}$ & 0.783 & $\begin{array}{c}0.0102 \\
(0.0051)\end{array}$ & $\begin{array}{c}2.42 \\
(0.06)\end{array}$ \\
\hline & men & 0.894 & $\begin{array}{l}-0.0020 \\
(0.0014)\end{array}$ & $\begin{array}{l}1.00 \\
(0.39)\end{array}$ & 0.755 & $\begin{array}{c}0.0088 \\
(0.0061)\end{array}$ & $\begin{array}{c}1.54 \\
(0.20)\end{array}$ \\
\hline \multirow[t]{2}{*}{ College entrant } & women & 0.532 & $\begin{array}{l}-0.0018 \\
(0.0023)\end{array}$ & $\begin{array}{c}1.46 \\
(0.22)\end{array}$ & 0.411 & $\begin{array}{c}0.0153 \\
(0.0060)\end{array}$ & $\begin{array}{c}2.75 \\
(0.04)\end{array}$ \\
\hline & men & 0.580 & $\begin{array}{c}0.0043 \\
(0.0023)\end{array}$ & $\begin{array}{c}1.32 \\
(0.27)\end{array}$ & 0.387 & $\begin{array}{c}0.0093 \\
(0.0068)\end{array}$ & $\begin{array}{c}1.43 \\
(0.12)\end{array}$ \\
\hline \multirow[t]{2}{*}{ College graduate } & women & 0.249 & $\begin{array}{c}0.0023 \\
(0.0020)\end{array}$ & $\begin{array}{c}0.68 \\
(0.56)\end{array}$ & 0.139 & $\begin{array}{c}0.0134 \\
(0.0043)\end{array}$ & $\begin{array}{c}4.32 \\
(0.01)\end{array}$ \\
\hline & men & 0.292 & $\begin{array}{l}-0.0017 \\
(0.0021)\end{array}$ & $\begin{array}{c}0.34 \\
(0.80)\end{array}$ & 0.122 & $\begin{array}{l}-0.0022 \\
(0.0046)\end{array}$ & $\begin{array}{c}1.68 \\
(0.17)\end{array}$ \\
\hline \multirow[t]{2}{*}{ Ycars of education } & women & 13.33 & $\begin{array}{l}-0.0158 \\
(0.0113)\end{array}$ & $\begin{array}{c}1.14 \\
(0.33)\end{array}$ & 12.52 & $\begin{array}{c}0.0504 \\
(0.0298)\end{array}$ & $\begin{array}{c}1.25 \\
(0.29)\end{array}$ \\
\hline & men & 13.58 & $\begin{array}{l}-0.0099 \\
(0.0126)\end{array}$ & $\begin{array}{c}1.14 \\
(0.33)\end{array}$ & 12.34 & $\begin{array}{c}0.0229 \\
(0.0353)\end{array}$ & $\begin{array}{c}0.50 \\
(0.68)\end{array}$ \\
\hline \multirow[t]{2}{*}{ In poverty } & women & 0.077 & $\begin{array}{c}0.0002 \\
(0.0012)\end{array}$ & $\begin{array}{c}1.84 \\
(0.14)\end{array}$ & 0.256 & $\begin{array}{l}-0.0017 \\
(0.0054)\end{array}$ & $\begin{array}{c}1.03 \\
(0.38)\end{array}$ \\
\hline & men & 0.060 & $\begin{array}{c}0.0011 \\
(0.0011)\end{array}$ & $\begin{array}{c}1.36 \\
(0.25)\end{array}$ & 0.166 & $\begin{array}{c}0.0043 \\
(0.0053)\end{array}$ & $\begin{array}{c}0.44 \\
(0.73)\end{array}$ \\
\hline \multirow[t]{2}{*}{ Worked } & women & 0.734 & $\begin{array}{c}0.0018 \\
(0.0021)\end{array}$ & $\begin{array}{c}1.69 \\
(0.17)\end{array}$ & 0.748 & $\begin{array}{c}0.0118 \\
(0.0054)\end{array}$ & $\begin{array}{c}2.92 \\
(0.03)\end{array}$ \\
\hline & men & 0.891 & $\begin{array}{l}-0.0001 \\
(0.0015)\end{array}$ & $\begin{array}{c}0.05 \\
(0.99)\end{array}$ & 0.821 & $\begin{array}{l}-0.0012 \\
(0.0054)\end{array}$ & $\begin{array}{c}0.27 \\
(0.85)\end{array}$ \\
\hline \multirow[t]{2}{*}{ Log labor earnings } & women & 9.038 & $\begin{array}{l}-0.0103 \\
(0.0060)\end{array}$ & $\begin{array}{c}1.38 \\
(0.29)\end{array}$ & 9.048 & $\begin{array}{l}-0.0072 \\
(0.0147)\end{array}$ & $\begin{array}{c}1.01 \\
(0.39)\end{array}$ \\
\hline & men & 9.772 & $\begin{array}{l}-0.0128 \\
(0.0040)\end{array}$ & $\begin{array}{c}5.91 \\
(0.001)\end{array}$ & 9.294 & $\begin{array}{l}-0.0158 \\
(0.0155)\end{array}$ & $\begin{array}{c}0.69 \\
(0.56)\end{array}$ \\
\hline
\end{tabular}

The table reports OLS estimates of the effect of a dummy for any exposure to abortion reform on a variety of outcomes using pooled samples from the 1980 and 1990 censuses. All models include a full set of year of birth times census year and state of birth times census year interactions. 
Table 6

Least-Square Estimates, First Stage Outcomes

1955-1959 Birth Cohorts

Women

1980 Census PUMS

by Race

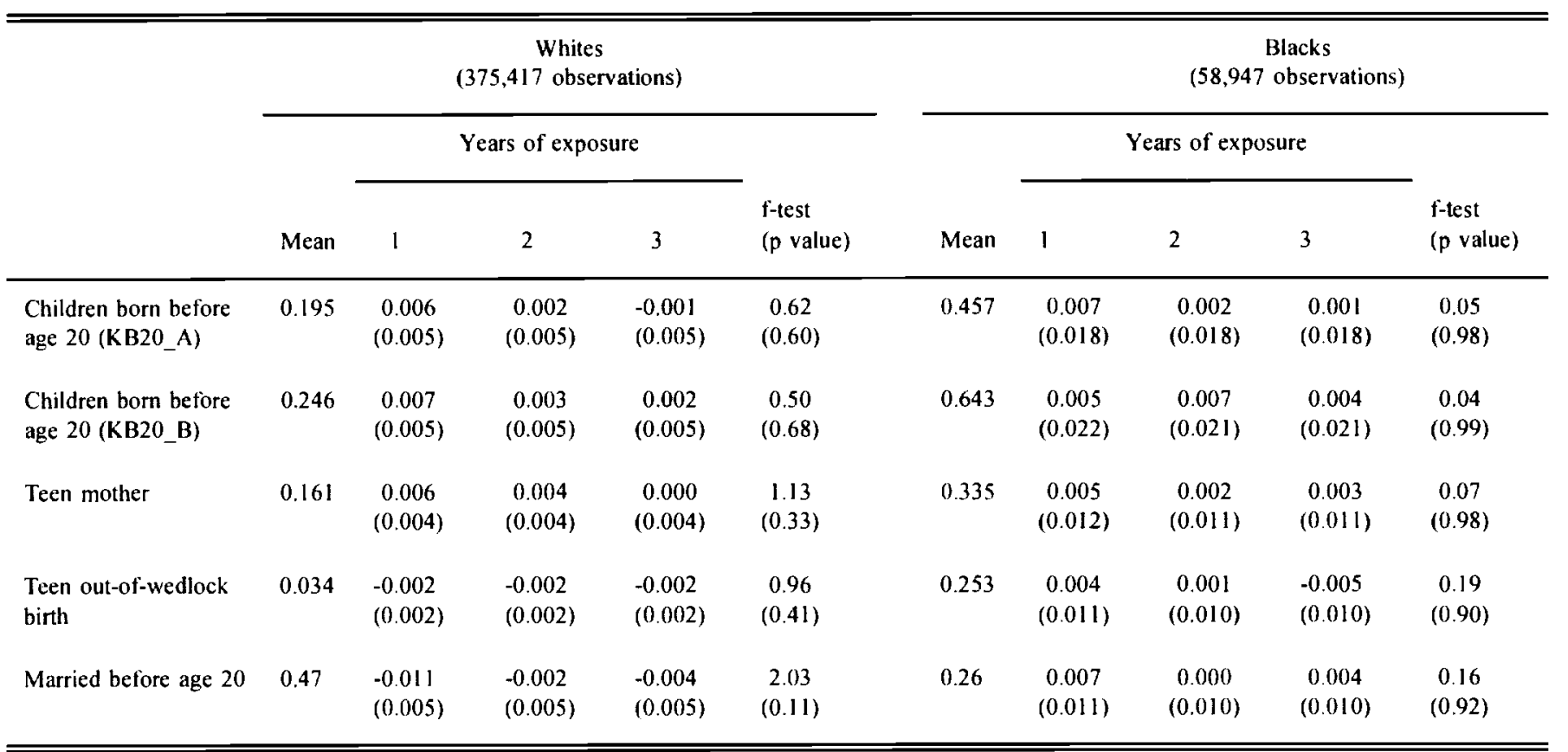

The tables reports OLS estimates of the effect of 3 exposure dummies on first-stage outcomes for women born 1955-59 in the 1980 Census. F-statistics are for the joint significance of 3 exposure dummies. All models include year of birth effects and state of birth effects. 
Table 7

2SLS and SSIV Estimates.

Black Women

1949-1954 Birth Cohorts

1980 PUMS: 2SLS

\begin{tabular}{|c|c|c|c|c|c|c|c|c|c|c|c|c|c|c|c|c|}
\hline & $\underline{\mathrm{Hig}}$ & school gr & luate & & & llege entr & & & & In Poverty & & & & Worked & & \\
\hline $\begin{array}{l}\text { Independent } \\
\text { Variable }\end{array}$ & OLS & $\begin{array}{l}2 S L S \\
\text { (a) }\end{array}$ & $\begin{array}{l}2 \text { SLS } \\
\text { (b) }\end{array}$ & $\begin{array}{l}2 \text { SLS } \\
\text { (c) }\end{array}$ & OLS & $\begin{array}{l}2 \text { SLS } \\
\text { (a) }\end{array}$ & $\begin{array}{l}2 S L S \\
\text { (b) }\end{array}$ & $\begin{array}{l}2 S L S \\
\text { (c) }\end{array}$ & OLS & $\begin{array}{l}2 \text { SLS } \\
\text { (a) }\end{array}$ & $\begin{array}{l}2 S L S \\
\text { (b) }\end{array}$ & $\begin{array}{l}2 S L S \\
\text { (c) }\end{array}$ & OLS & $\begin{array}{l}2 S L S \\
\text { (a) }\end{array}$ & $\begin{array}{l}2 \text { SLS } \\
\text { (b) }\end{array}$ & $\begin{array}{l}2 S L S \\
\text { (c) }\end{array}$ \\
\hline $\begin{array}{l}\text { Children born } \\
\text { before 20 } \\
\text { (KB20_B) }\end{array}$ & $\begin{array}{l}-0.134 \\
(0.002)\end{array}$ & $\begin{array}{l}-0.227 \\
(0.115)\end{array}$ & $\begin{array}{l}-0.236 \\
(0.113)\end{array}$ & $\begin{array}{l}-0.220 \\
(0.101)\end{array}$ & $\begin{array}{l}-0.122 \\
(0.002)\end{array}$ & $\begin{array}{l}-0.266 \\
(0.135)\end{array}$ & $\begin{array}{l}-0.233 \\
(0.130)\end{array}$ & $\begin{array}{l}-0.240 \\
(0.117)\end{array}$ & $\begin{array}{c}0.103 \\
(0.002)\end{array}$ & $\begin{array}{c}0.019 \\
(0.123)\end{array}$ & $\begin{array}{c}0.037 \\
(0.120)\end{array}$ & $\begin{array}{c}0.049 \\
(0.107)\end{array}$ & $\begin{array}{l}-0.067 \\
(0.002)\end{array}$ & $\begin{array}{l}-0.246 \\
(0.135)\end{array}$ & $\begin{array}{l}-0.280 \\
(0.136)\end{array}$ & $\begin{array}{l}-0.270 \\
(0.121)\end{array}$ \\
\hline$\chi^{2}[\mathrm{df}]$ & & & $5.60[2]$ & $1.80[1]$ & & & $1.96[2]$ & $0.03[1]$ & & & $0.93[2]$ & $0.79[1]$ & & & $3.24[2]$ & $0.03[1]$ \\
\hline $\begin{array}{l}\text { Teen out-of- } \\
\text { wedlock birth }\end{array}$ & $\begin{array}{l}-0.185 \\
(0.004)\end{array}$ & $\begin{array}{l}-0.474 \\
(0.254)\end{array}$ & $\begin{array}{l}-0.224 \\
(0.219)\end{array}$ & $\begin{array}{l}-0.506 \\
(0.258)\end{array}$ & $\begin{array}{l}-0.205 \\
(0.004)\end{array}$ & $\begin{array}{l}-0.557 \\
(0.288)\end{array}$ & $\begin{array}{l}-0.435 \\
(0.244)\end{array}$ & $\begin{array}{l}-0.571 \\
(0.292)\end{array}$ & $\begin{array}{c}0.187 \\
(0.004)\end{array}$ & $\begin{array}{c}0.039 \\
(0.259)\end{array}$ & $\begin{array}{c}0.138 \\
(0.223)\end{array}$ & $\begin{array}{c}0.138 \\
(0.258)\end{array}$ & $\begin{array}{l}-0.090 \\
(0.004)\end{array}$ & $\begin{array}{l}-0.514 \\
(0.284)\end{array}$ & $\begin{array}{l}-0.380 \\
(0.237)\end{array}$ & $\begin{array}{l}-0648 \\
(0.301)\end{array}$ \\
\hline$\chi^{2}[\mathrm{df}]$ & & & $8.72[2]$ & $1.89[1]$ & & & $1.94[2]$ & $0.08[1]$ & & & $0.64[2]$ & $0.73[1]$ & & & $5.93[2]$ & $0.01[1]$ \\
\hline
\end{tabular}

1990 PUMS: SSIV

\begin{tabular}{|c|c|c|c|c|c|c|c|c|c|c|c|c|}
\hline & High school gra & luate & & College entr: & & & $\underline{\text { In povert }}$ & & & Worked & & \\
\hline $\begin{array}{l}\text { Independent } \\
\text { Variable }\end{array}$ & $\begin{array}{l}\text { 2SLS } \\
\text { (a) }\end{array}$ & $\begin{array}{l}2 S L S \\
\text { (b) }\end{array}$ & $\begin{array}{l}2 S L S \\
\text { (c) }\end{array}$ & $\begin{array}{l}2 S L S \\
\text { (a) }\end{array}$ & $\begin{array}{l}2 \text { SLS } \\
\text { (b) }\end{array}$ & $\begin{array}{l}2 \mathrm{SLS} \\
\text { (c) }\end{array}$ & $\begin{array}{l}2 S L S \\
\text { (a) }\end{array}$ & $\begin{array}{l}\text { 2SLS } \\
\text { (b) }\end{array}$ & $\begin{array}{l}2 S L S \\
\text { (c) }\end{array}$ & $\begin{array}{l}\text { 2SLS } \\
\text { (a) }\end{array}$ & $\begin{array}{l}2 S L S \\
\text { (b) }\end{array}$ & $\begin{array}{l}2 S L S \\
\text { (c) }\end{array}$ \\
\hline $\begin{array}{l}\text { Children born } \\
\text { before } 20 \\
\text { (KB20_B) }\end{array}$ & $\begin{array}{l}-0.103 \\
(0.120)\end{array}$ & $\begin{array}{l}-0.082 \\
(0.117)\end{array}$ & $\begin{array}{l}-0.048 \\
(0.118)\end{array}$ & $\begin{array}{l}-0.236 \\
(0.149)\end{array}$ & $\begin{array}{l}-0.292 \\
(0.145)\end{array}$ & $\begin{array}{l}-0.234 \\
(0.146)\end{array}$ & $\begin{array}{c}0.038 \\
(0.128)\end{array}$ & $\begin{array}{c}0.064 \\
(0.125)\end{array}$ & $\begin{array}{c}0.076 \\
(0.126)\end{array}$ & $\begin{array}{l}-0.135 \\
(0.125)\end{array}$ & $\begin{array}{l}-0.147 \\
(0.121)\end{array}$ & $\begin{array}{l}-0.143 \\
(0.123)\end{array}$ \\
\hline $\begin{array}{l}\text { Teen out-of- } \\
\text { wedlock birth }\end{array}$ & $\begin{array}{l}-0.216 \\
(0.250)\end{array}$ & $\begin{array}{l}-0.106 \\
(0.217)\end{array}$ & $\begin{array}{l}-0.122 \\
(0.248)\end{array}$ & $\begin{array}{l}-0.493 \\
(0.311)\end{array}$ & $\begin{array}{l}-0.611 \\
(0.270)\end{array}$ & $\begin{array}{l}-0.493 \\
(0.308)\end{array}$ & $\begin{array}{c}0.080 \\
(0.268)\end{array}$ & $\begin{array}{c}0.229 \\
(0.232)\end{array}$ & $\begin{array}{c}0.147 \\
(0.264)\end{array}$ & $\begin{array}{l}-0.282 \\
(0.261)\end{array}$ & $\begin{array}{l}-0.296 \\
(0.226)\end{array}$ & $\begin{array}{l}-0.209 \\
(0.258)\end{array}$ \\
\hline
\end{tabular}


Table 7 (continued)

1980 and 1990 Stacked: SSIV

\begin{tabular}{|c|c|c|c|c|c|c|c|c|c|c|c|c|}
\hline \multirow[b]{2}{*}{$\begin{array}{l}\text { Independent } \\
\text { Variable }\end{array}$} & \multicolumn{3}{|c|}{ High school graduate } & \multicolumn{3}{|c|}{ College entrant } & \multicolumn{3}{|c|}{ In poverty } & \multicolumn{3}{|l|}{ Worked } \\
\hline & $\begin{array}{l}2 \text { SLS } \\
\text { (a) }\end{array}$ & $\begin{array}{l}2 S L S \\
\text { (b) }\end{array}$ & $\begin{array}{l}2 S L S \\
\text { (c) }\end{array}$ & $\begin{array}{l}\text { 2SLS } \\
\text { (a) }\end{array}$ & $\begin{array}{l}\text { 2SL.S } \\
\text { (b) }\end{array}$ & $\begin{array}{l}2 \text { Sl.S } \\
\text { (c) }\end{array}$ & $\begin{array}{l}2 S L S \\
\text { (a) }\end{array}$ & $\begin{array}{l}2 S L S \\
\text { (b) }\end{array}$ & $\begin{array}{l}2 \text { SLS } \\
\text { (c) }\end{array}$ & $\begin{array}{l}2 \text { SLS } \\
\text { (a) }\end{array}$ & $\begin{array}{l}2 S L S \\
\text { (b) }\end{array}$ & $\begin{array}{l}\text { 2SLS } \\
\text { (c) }\end{array}$ \\
\hline $\begin{array}{l}\text { Children born } \\
\text { before } 20 \\
\text { (KB20_B) }\end{array}$ & $\begin{array}{l}-0.169 \\
(0.084)\end{array}$ & $\begin{array}{l}-0.164 \\
(0.082)\end{array}$ & $\begin{array}{l}-0.128 \\
(0.082)\end{array}$ & $\begin{array}{l}-0.252 \\
(0.099)\end{array}$ & $\begin{array}{l}-0.261 \\
(0.097)\end{array}$ & $\begin{array}{l}-0.247 \\
(0.098)\end{array}$ & $\begin{array}{c}0.027 \\
(0.089)\end{array}$ & $\begin{array}{c}0.049 \\
(0.087)\end{array}$ & $\begin{array}{c}0.058 \\
(0.088)\end{array}$ & $\begin{array}{l}-0.194 \\
(0.089)\end{array}$ & $\begin{array}{l}-0.217 \\
(0.086)\end{array}$ & $\begin{array}{l}-0.202 \\
(0.087)\end{array}$ \\
\hline $\begin{array}{l}\text { Teen out-of- } \\
\text { wedlock birth }\end{array}$ & $\begin{array}{l}-0.353 \\
(0.176)\end{array}$ & $\begin{array}{l}-0.168 \\
(0.153)\end{array}$ & $\begin{array}{l}-0.284 \\
(0.174)\end{array}$ & $\begin{array}{l}-0.527 \\
(0.208)\end{array}$ & $\begin{array}{l}-0.518 \\
(0.181)\end{array}$ & $\begin{array}{l}-0.521 \\
(0.205)\end{array}$ & $\begin{array}{c}0.058 \\
(0.187)\end{array}$ & $\begin{array}{c}0.181 \\
(0.163)\end{array}$ & $\begin{array}{c}0.112 \\
(0.184)\end{array}$ & $\begin{array}{l}-0.406 \\
(0.186)\end{array}$ & $\begin{array}{l}-0.341 \\
(0.161)\end{array}$ & $\begin{array}{l}-0.422 \\
(0.183)\end{array}$ \\
\hline
\end{tabular}

All models include state of birth and year of birth effects. The second-stage of the stacked SSIV estimates include separate state of birth and year of birth effects for the two census years. 2 SLS (a) uses an indicator for any positive exposure as the instrument. 2SLS (b) utilizes indicators for 1,2, and 3 years of exposure as instruments. 2SLS(c) uses any exposure time a two-level severity ranking of the state law. 
Table B1

Least-Square Estimates, First and Second Stage Outcomes

1949-1954 Birth Cohorts

1980 Census PUMS

by Sex and Race

\begin{tabular}{|c|c|c|c|c|c|c|c|c|c|}
\hline \multirow[b]{2}{*}{ First-stage outcomes } & \multirow[b]{2}{*}{ Sample } & \multicolumn{4}{|c|}{$\begin{array}{c}\text { Whites } \\
(420,920 \text { observations for women, } \\
417,812 \text { for men })\end{array}$} & \multicolumn{4}{|c|}{$\begin{array}{c}\text { Blacks } \\
(61,778 \text { observations for women, } \\
51,371 \text { for men) }\end{array}$} \\
\hline & & Mean & $\begin{array}{r}\text { All } \\
\text { states }\end{array}$ & $\begin{array}{l}\text { No border } \\
\text { states }\end{array}$ & $\begin{array}{c}\text { State- } \\
\text { matching }\end{array}$ & Mean & $\begin{array}{r}\text { All } \\
\text { states }\end{array}$ & $\begin{array}{l}\text { No border } \\
\text { states }\end{array}$ & $\begin{array}{c}\text { State- } \\
\text { matching }\end{array}$ \\
\hline $\begin{array}{l}\text { Children born before } \\
\text { Age } 20 \text { (KB20_A) }\end{array}$ & women & 0.231 & $\begin{array}{l}-0.0019 \\
(0.0035) \\
(0.0034)\end{array}$ & $\begin{array}{l}-0.0022 \\
(0.0039) \\
(0.0039)\end{array}$ & $\begin{array}{l}-0.0033 \\
(0.0066) \\
(0.0066)\end{array}$ & 0.564 & $\begin{array}{l}-0.0488 \\
(0.0139) \\
(0.0138)\end{array}$ & $\begin{array}{l}-0.0459 \\
(0.0175) \\
(0.0176)\end{array}$ & $\begin{array}{l}-0.0859 \\
(0.0445) \\
(0.0449)\end{array}$ \\
\hline $\begin{array}{l}\text { Children born before } \\
\text { Age } 20 \text { (KB20_B) }\end{array}$ & women & 0.310 & $\begin{array}{l}-0.0066 \\
(0.0043) \\
(0.0043)\end{array}$ & $\begin{array}{l}-0.0092 \\
(0.0049) \\
(0.0049)\end{array}$ & $\begin{array}{c}0.0033 \\
(0.0081) \\
(0.0082)\end{array}$ & 0.796 & $\begin{array}{l}-0.0607 \\
(0.0178) \\
(0.0178)\end{array}$ & $\begin{array}{l}-0.0738 \\
(0.0223) \\
(0.0223)\end{array}$ & $\begin{array}{l}-0.0396 \\
(0.0577) \\
(0.0590)\end{array}$ \\
\hline $\begin{array}{l}\text { Teen out-of-wedlock } \\
\text { birth }\end{array}$ & women & 0.033 & $\begin{array}{c}0.0008 \\
(0.0012) \\
(0.0012)\end{array}$ & $\begin{array}{c}0.0000 \\
(0.0014) \\
(0.0014)\end{array}$ & $\begin{array}{c}0.0022 \\
(0.0024) \\
(0.0023)\end{array}$ & 0.251 & $\begin{array}{l}-0.0290 \\
(0.0074) \\
(0.0074)\end{array}$ & $\begin{array}{l}-0.0304 \\
(0.0094) \\
(0.0094)\end{array}$ & $\begin{array}{l}-0.0578 \\
(0.0242) \\
(0.0243)\end{array}$ \\
\hline \multirow[t]{2}{*}{$\begin{array}{l}\text { Married before age } \\
20\end{array}$} & women & 0.56 & $\begin{array}{l}-0.0158 \\
(0.0033) \\
(0.0033)\end{array}$ & $\begin{array}{l}-0.0154 \\
(0.0039) \\
(0.0039)\end{array}$ & $\begin{array}{l}-0.0170 \\
(0.0066) \\
(0.0067)\end{array}$ & 0.399 & $\begin{array}{l}-0.0209 \\
(0.0084) \\
(0.0083)\end{array}$ & $\begin{array}{l}-0.0103 \\
(0.0106) \\
(0.0106)\end{array}$ & $\begin{array}{l}-0.0345 \\
(0.0269) \\
(0.0274)\end{array}$ \\
\hline & men & 0.16 & $\begin{array}{l}-0.0050 \\
(0.0025) \\
(0.0024)\end{array}$ & $\begin{array}{l}-0.0042 \\
(0.0028) \\
(0.0028)\end{array}$ & $\begin{array}{c}0.0002 \\
(0.0048) \\
(0.0046)\end{array}$ & 0.136 & $\begin{array}{l}-0.0048 \\
(0.0064) \\
(0.0063)\end{array}$ & $\begin{array}{l}-0.0053 \\
(0.0079) \\
(0.0080)\end{array}$ & $\begin{array}{l}-0.0210 \\
(0.0200) \\
(0.0210)\end{array}$ \\
\hline
\end{tabular}


Table B1 (continued)

\begin{tabular}{|c|c|c|c|c|c|c|c|c|c|}
\hline Second-stage outcomes & Sample & Mean & $\begin{array}{r}\text { All } \\
\text { states }\end{array}$ & $\begin{array}{l}\text { No border } \\
\text { states }\end{array}$ & $\begin{array}{c}\text { State- } \\
\text { matching }\end{array}$ & Mean & $\begin{array}{r}\text { All } \\
\text { states }\end{array}$ & $\begin{array}{l}\text { No border } \\
\text { states }\end{array}$ & $\begin{array}{c}\text { State- } \\
\text { matching }\end{array}$ \\
\hline \multirow[t]{2}{*}{ High school graduate } & women & 0.884 & $\begin{array}{c}-0.0038 \\
(0.0021) \\
(0.0021)\end{array}$ & $\begin{array}{l}-0.0002 \\
(0.0024) \\
(0.0024)\end{array}$ & $\begin{array}{l}-0.0068 \\
(0.0042) \\
(0.0040)\end{array}$ & 0.768 & $\begin{array}{c}0.0138 \\
(0.0072) \\
(0.0072)\end{array}$ & $\begin{array}{c}0.0119 \\
(0.0090) \\
(0.0089)\end{array}$ & $\begin{array}{c}0.0143 \\
(0.0240) \\
(0.0243)\end{array}$ \\
\hline & men & 0.884 & $\begin{array}{l}-0.0011 \\
(0.0021) \\
(0.0021)\end{array}$ & $\begin{array}{c}0.0000 \\
(0.0024) \\
(0.0024)\end{array}$ & $\begin{array}{l}-0.0022 \\
(0.0043) \\
(0.0040)\end{array}$ & 0.745 & $\begin{array}{c}0.0085 \\
(0.0081) \\
(0.0082)\end{array}$ & $\begin{array}{c}0.0143 \\
(0.0103) \\
(0.0102)\end{array}$ & $\begin{array}{c}-0.0166 \\
(0.0267) \\
(0.0272)\end{array}$ \\
\hline \multirow[t]{2}{*}{ College entrant } & women & 0.458 & $\begin{array}{c}-0.0022 \\
(0.0033) \\
(0.0033)\end{array}$ & $\begin{array}{c}0.0045 \\
(0.0039) \\
(0.0039)\end{array}$ & $\begin{array}{c}-0.0111 \\
(0.0067) \\
(0.0067)\end{array}$ & 0.346 & $\begin{array}{c}0.0162 \\
(0.0081) \\
(0.0081)\end{array}$ & $\begin{array}{c}0.0155 \\
(0.0103) \\
(0.0104)\end{array}$ & $\begin{array}{c}0.0275 \\
(0.0259) \\
(0.0252)\end{array}$ \\
\hline & men & 0.522 & $\begin{array}{c}0.0023 \\
(0.0033) \\
(0.0033)\end{array}$ & $\begin{array}{c}0.0063 \\
(0.0039) \\
(0.0039)\end{array}$ & $\begin{array}{l}-0.0006 \\
(0.0067) \\
(0.0067)\end{array}$ & 0.336 & $\begin{array}{c}0.0070 \\
(0.0088) \\
(0.0088)\end{array}$ & $\begin{array}{c}0.0143 \\
(0.0112) \\
(0.0112)\end{array}$ & $\begin{array}{c}-0.0280 \\
(0.0276) \\
(0.0269)\end{array}$ \\
\hline Worker & men & 0.906 & $\begin{array}{l}-0.0008 \\
(0.0020) \\
(0.0020)\end{array}$ & $\begin{array}{l}-0.0024 \\
(0.0023) \\
(0.0023)\end{array}$ & $\begin{array}{c}0.0037 \\
(0.0040) \\
(0.0040)\end{array}$ & 0.834 & $\begin{array}{c}0.0084 \\
(0.0070) \\
(0.0069)\end{array}$ & $\begin{array}{c}0.0055 \\
(0.0089) \\
(0.0090)\end{array}$ & $\begin{array}{c}0.0293 \\
(0.0227) \\
(0.0217)\end{array}$ \\
\hline \multirow[t]{2}{*}{ In poverty } & women & 0.083 & $\begin{array}{c}0.0008 \\
(0.0019) \\
(0.0019)\end{array}$ & $\begin{array}{c}0.0014 \\
(0.0021) \\
(0.0021)\end{array}$ & $\begin{array}{l}-0.0029 \\
(0.0038) \\
(0.0037)\end{array}$ & 0.269 & $\begin{array}{l}-0.0011 \\
(0.0076) \\
(0.0075)\end{array}$ & $\begin{array}{l}-0.0060 \\
(0.0095) \\
(0.0095)\end{array}$ & $\begin{array}{c}0.0041 \\
(0.0250) \\
(0.0246)\end{array}$ \\
\hline & men & 0.058 & $\begin{array}{c}0.0044 \\
(0.0016) \\
(0.0016)\end{array}$ & $\begin{array}{c}0.0043 \\
(0.0018) \\
(0.0018)\end{array}$ & $\begin{array}{c}0.0075 \\
(0.0033) \\
(0.0031)\end{array}$ & 0.142 & $\begin{array}{l}-0.0015 \\
(0.0066) \\
(0.0065)\end{array}$ & $\begin{array}{c}0.0086 \\
(0.0083) \\
(0.0084)\end{array}$ & $\begin{array}{l}-0.0361 \\
(0.0217) \\
(0.0205)\end{array}$ \\
\hline
\end{tabular}

All models include year of birth effects and state of birth effects. 
Table B2:

Matched State Pairs for Table B2

\begin{tabular}{|c|c|c|c|c|c|}
\hline \multicolumn{3}{|c|}{ a: State groups for whites } & \multicolumn{3}{|c|}{ b: State groups for blacks } \\
\hline $\begin{array}{l}\text { Quintiles } \\
\text { (education, } \\
\text { fertility) }\end{array}$ & Reform & Non-reform & $\begin{array}{l}\text { Quintiles } \\
\text { (education, } \\
\text { fertility) }\end{array}$ & Reform & Non-reform \\
\hline$(1,3)$ & South Carolina & $\begin{array}{l}\text { Georgia } \\
\text { Tennessee }\end{array}$ & $(1,4)$ & $\begin{array}{l}\text { Deleware } \\
\text { Hawaii } \\
\text { South Caro }\end{array}$ & Georgia \\
\hline$(1,5)$ & Arkansas & $\begin{array}{l}\text { Kentucky } \\
\text { West Virginia }\end{array}$ & $(1,5)$ & Alaska & $\begin{array}{l}\text { Mississippi } \\
\text { Montana } \\
\text { Wyoming }\end{array}$ \\
\hline$(2,5)$ & New Mexico & $\begin{array}{l}\text { Arizona } \\
\text { Louisiana } \\
\text { Vermont }\end{array}$ & $(2,5)$ & Arkansas & Kentucky \\
\hline$(4,1)$ & Alaska & Rhode Island & $(4,1)$ & Colorado & District of Columbia \\
\hline$(4,2)$ & $\begin{array}{l}\text { Oregon } \\
\text { Washington }\end{array}$ & Illinois & $(5,1)$ & Oregon & $\begin{array}{l}\text { Massachusetts } \\
\text { Nebraska } \\
\text { South Dakota } \\
\text { Vermont }\end{array}$ \\
\hline$(4,3)$ & Colorado & Minnesota & $(5,2)$ & $\begin{array}{l}\text { California } \\
\text { New York }\end{array}$ & lowa \\
\hline$(4,4)$ & Kansas & Nebraska & & & \\
\hline$(5,1)$ & $\begin{array}{l}\text { California } \\
\text { Hawaii } \\
\text { New York }\end{array}$ & $\begin{array}{l}\text { Connecticut } \\
\text { District of Columbia } \\
\text { Massachusetts } \\
\text { New Jersey }\end{array}$ & & & \\
\hline \multicolumn{3}{|c|}{$\begin{array}{l}\text { Unmatched reform states: North Carolina }(1,2) \text {; Virginia }(1,2) \text {; } \\
\text { Maryland }(3,3) \text {; Delaware }(2,2) \text {. }\end{array}$} & \multicolumn{3}{|c|}{$\begin{array}{l}\text { Unmatched reform states: North Carolina }(2,3) \text {; Virginia }(2,2) \text {; } \\
\text { Maryland }(2,2) \text {; Washington }(3,2) \text {; Kansas }(5,2) \text {; New Mexico }(5,5) \text {. }\end{array}$} \\
\hline
\end{tabular}

Notes: Matching based on average years of schooling and number of children ever born among women born 1949-50. 
Figure 1

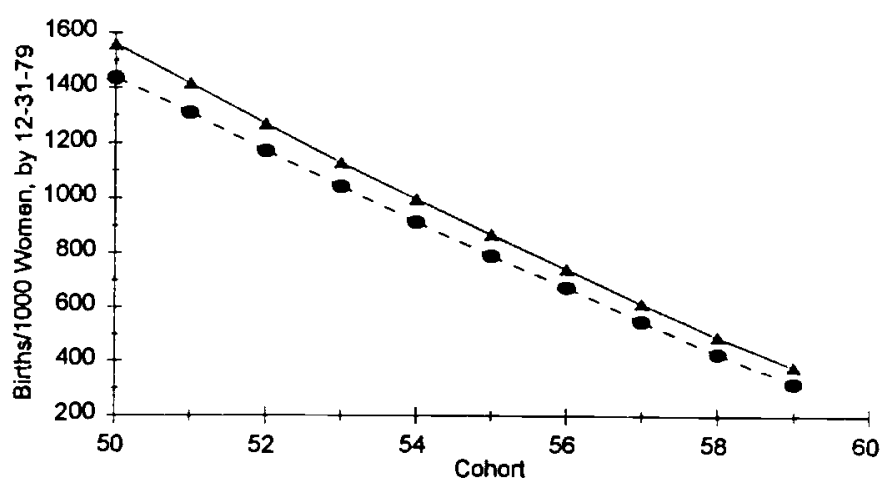

- Vital Statistics - 1980 PUMS

Figure 2

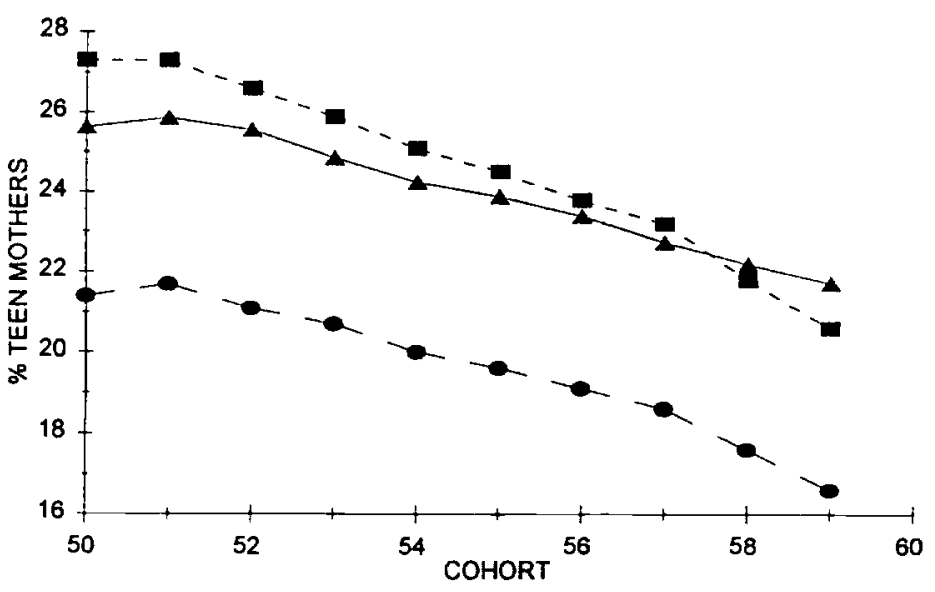

Figure 3

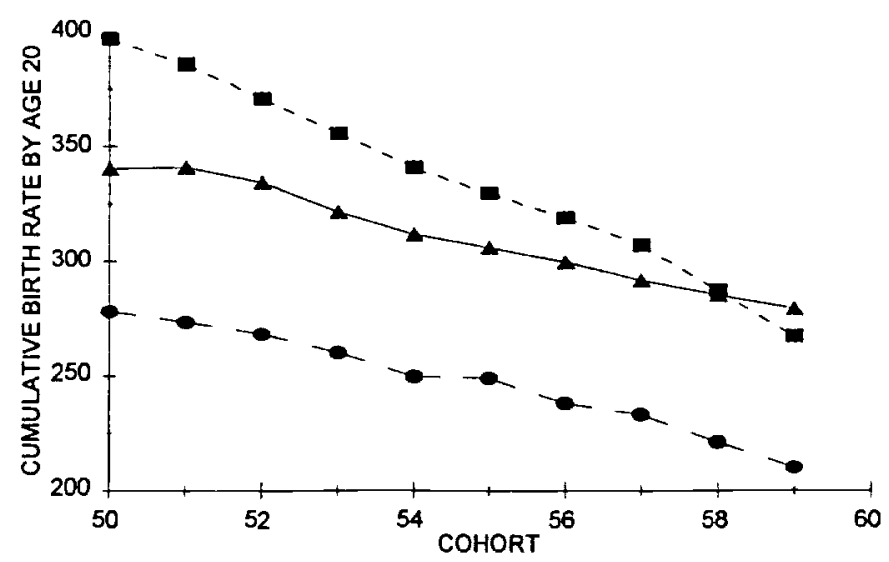


Figure 4

a: Avg children born before age 20 Whites

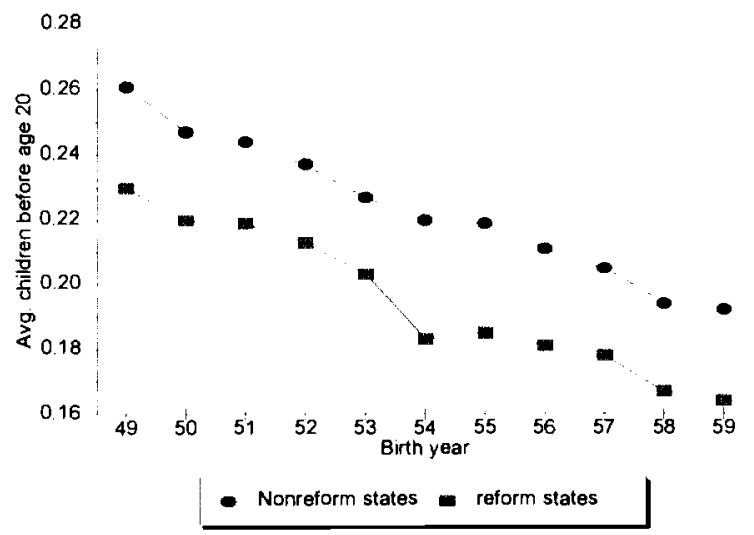

c: \% Married before age 20

White females

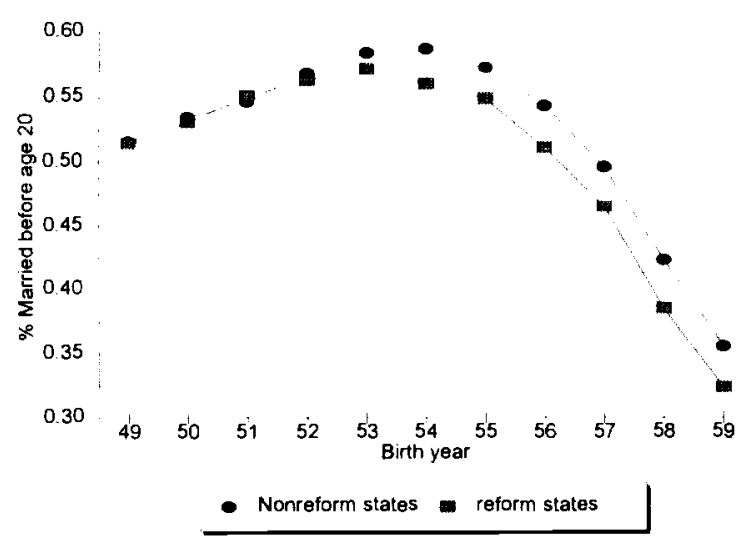

e: \% College entrants White females

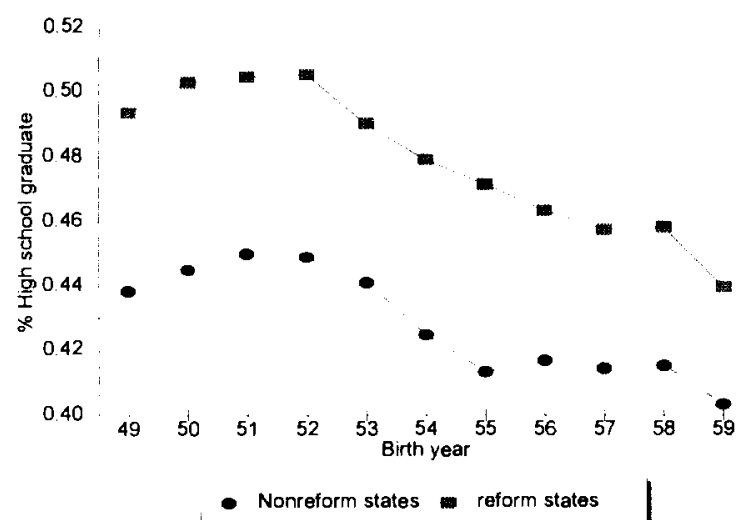

b: Avg. children born before age 20 Blacks

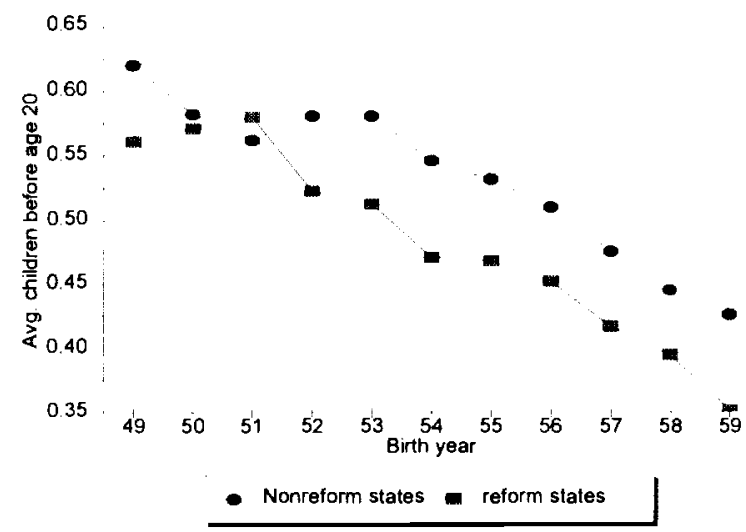

d: $\%$ Married before age 20 black females

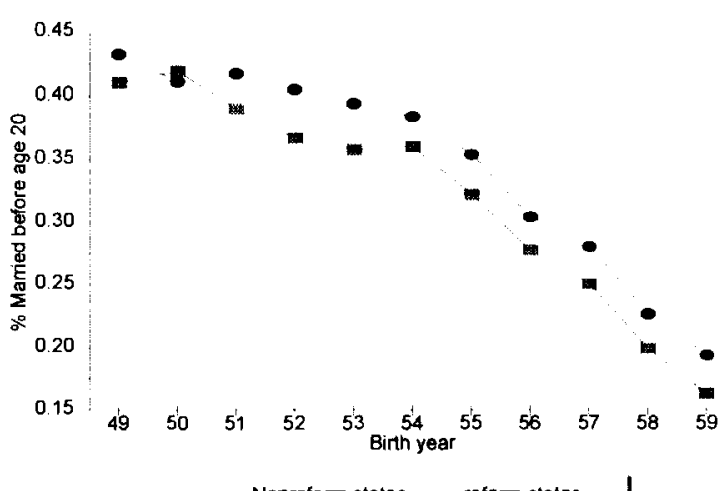

- Nonreform states w reform states

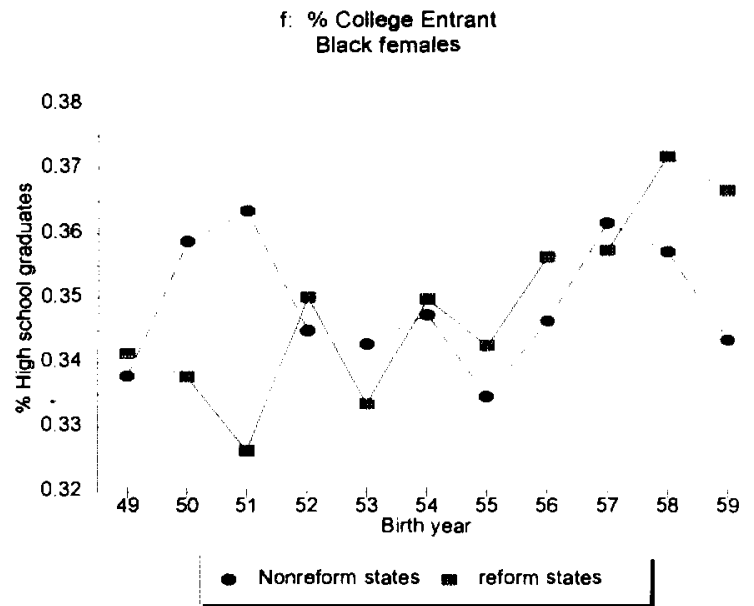

